\title{
Data report: petrophysical properties of "young" carbonate rocks (Tahiti Reef Tract, French Polynesia)'
}

\author{
Klaas Verwer ${ }^{2,3}$ and Hendrik Braaksma ${ }^{4,5}$
}

\section{Chapter contents}

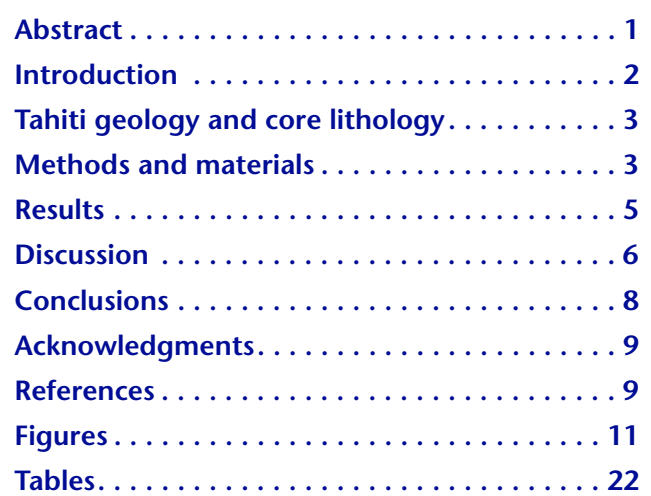

'Verwer, K., and Braaksma, H., 2009. Data report: petrophysical properties of "young" carbonate rocks (Tahiti Reef Tract, French Polynesia). In Camoin, G.F., Iryu, Y., McInroy, D.B., and the Expedition 310 Scientists, Proc. IODP, 310: Washington, DC (Integrated Ocean Drilling Program Management International, Inc.). doi:10.2204/iodp.proc.310.203.2009

${ }^{2}$ Faculty of Earth and Live Sciences, Vrije Universiteit, De Boelelaan 1085, 1081 HV Amsterdam, The Netherlands.

${ }^{3}$ Present address: Rosenstiel School of Marine and Atmospheric Science, University of Miami, 4600 Rickenbacker Causeway, Key Biscayne FL 33149, USA. kverwer@rsmas.miami.edu

${ }^{4}$ Laboratoire de Tectonophysique, Université Montpellier 2, 34095 Montpellier, France.

${ }^{5}$ Present address: ExxonMobil Upstream Research Company, 3120 Buffalo Speedway, Houston TX 77098, USA.

\section{Abstract}

We measured the acoustic properties and mineralogic compositions of 79 rock specimens from mixed carbonate-volcaniclastic minicores drilled from cores of the Holocene and Pleistocene reef tract in Tahiti, French Polynesia (Integrated Ocean Drilling Program Expedition 310). Three significant sediment groups with distinct physical properties were distinguished: coralgal-microbialite framework, coralgal-microbialite framework with dispersed volcaniclastic grains throughout the micrite matrix, and cemented volcaniclastic-skeletal sand and coral framework. Variations in acoustic velocity (porosity range $=1 \%-35 \%$ ) are primarily controlled by porosity, secondly by the ratio of carbonate-volcaniclastic material, and thirdly by the introduction of fringing cement. Linear regression fitting resulted in a velocity-porosity-carbonate content transform that predicts acoustic velocity at different levels of volcaniclastic contamination. The intersection point of the velocity-porosity transform with the zero-porosity axis decreases with decreasing carbonate content, which may be explained by the presence of clay minerals and organic content. Another observation is the property of magmatic minerals with high matrix velocity to positively affect the transmission properties of acoustic waves at high porosity. The Tahiti reefs are significant in the fact that the framework is formed by microbialite in association with coralgal reef systems. Microbialite is often volumetrically the most important component of the reef rock and forms a dense mass that is capable of withstanding extraneous particles being dispersed within the matrix. Carbonate-lithoclastic sand from an older underlying reef sequence displays different petrophysical behavior. The slope of the velocity-porosity transform is steep, with large data scatter that is controlled by the presence of fringing cement lining the grains. Cement-rich samples show positive deviations from the velocity-porosity transform, whereas cement-poor samples have relatively low velocity for a given porosity. For all sediment groups, Gardner's experimental curve underestimates the observed acoustic velocities, probably because it does not account for variations in texture, mineralogy, and pore geometry. The velocity-porosity transform by Wyllie describes observed acoustic velocity trends for the clean carbonate samples but significantly underestimates velocity when magmatic minerals are introduced into the matrix. These findings underline the significantly more complex acoustic behavior in mixed carbonate-volcaniclastic sedimentary rocks than in pure siliciclastics 
and pure carbonates where mineralogic composition and rock texture, respectively, explain most of the observed relationships between porosity and acoustic velocity.

\section{Introduction}

Understanding the controls of petrophysical properties of porous media is a key issue in interpreting data from seismic sections or from acoustic logs of sedimentary sequences.

Unfortunately, the unpredictable character of porosity in carbonates complicates the relationship between physical and geological properties. Carbonate sediments are prone to rapid and pervasive diagenetic alterations that change the mineralogy and pore structure within carbonate rocks. In particular, cementation and dissolution processes continuously modify the pore structure to create or destroy porosity. All of these modifications alter the elastic properties of the rock and, therefore, the acoustic velocity. The result is a dynamic relationship between primary depositional lithology, diagenesis, porosity, rock texture, and acoustic velocity (Anselmetti and Eberli, 1993). Mixed carbonate-clastic settings present a special challenge in this respect. Carbonate platforms attached or proximal to hinterland may suffer from clastic influx, particularly during periods of sea level fall or lowstand (e.g., Playford, 1980; Sonnenfeld and Cross, 1993; Rankey et al., 1999). Also during other moments of sea level position, riverine transport and oceanic longshore currents may carry clastic material into carbonate provinces (e.g., Dunbar and Dickens, 2003; Cunningham et al., 2003). Few studies exist that investigate acoustic velocity distribution in mixed carbonate-clastic sediments. Kenter and Ivanov (1995) investigated parameters controlling acoustic properties of separate carbonate and volcaniclastic sediments from Ocean Drilling Program Sites 866 (Early Cretaceous shallowwater carbonates, Resolution Guyot) and 869 (Late Cretaceous to Miocene sediment apron, Wodejebato Guyot and Pikini [formerly Bikini] Atoll). Kenter et al. (1997b) focused on mineralogical and diagenetic controls on acoustic properties of Permian samples from New Mexico. In a following study they used these measurement values for synthetic seismic modeling of large outcrop sections in the same study area (Kenter et al., 2001). Anselmetti et al. (1997) investigated the physical properties of Neogene subsurface deposits of the Florida Keys to document the inherent reflectivity of different lithologies and compared these with seismic-reflection patterns from offshore seismic lines.
Extensive work over the last few decades has established some relatively simple relations between acoustic velocities and important rock parameters such as porosity and density. The classic velocity transforms, Wyllie's time-average equation (Wyllie et al., 1956), Raymer-Hunt-Gardner's modified time-average equation (Raymer et al., 1980), and Gardner's empirical relation (Gardner et al., 1974), allow prediction of $P$-wave velocity from porosity or bulk density. Such transforms are simple and convenient but generally fail to account for variations in velocity at a given porosity value. For mixed carbonate-siliciclastics, such empirical relationships have substantial limitations because they do not take into account the type of porosity, diagenetic parameters, or mixed mineralogy. Global trends in most published data, however, do follow the time-average and Gardner's equation (Gardner et al., 1974). Recently, Kenter et al. (2007) published a new methodology to extract rock texture information from acoustic velocity data alone through cross-plots of Poisson's ratio versus $P$-wave velocity. Verwer et al. (2008) amended that specific diagenetic overprint can be postulated from the position of samples in that particular space. During Integrated Ocean Drilling Program Expedition 310 (Camoin et al., 2005) 37 boreholes across 22 sites were drilled around Tahiti Island (French Polynesia) (Fig. F1A) to accomplish the following objectives:

- To establish the course of postglacial sea level rise at Tahiti,

- To define sea-surface temperature (SST) variations for the region over the $20-10$ ka period, and

- To analyze the impact of sea-level changes on reef growth and geometry (Camoin et al., 2005).

To meet these objectives, the late deglacial reef sequence, which consists of successive reef terraces seaward of the living barrier reef, was cored from the DP Hunter (Fig. F1B) during October and November 2005. In addition to the mission's scientific objectives, the expedition provided the unique opportunity to study the physical characteristics of young carbonate sediments, Holocene and Pleistocene in age, prior to any diagenetic overprint, such as mechanical compaction or cementation and recrystallization.

In this paper we report on the controls on the acoustic properties of Holocene and Pleistocene "young" carbonate reef sediments recovered from Expedition 310 Sites M0005-M0026 (Camoin et al., 2005). The analysis makes use of the combined petrophysical and petrographical approach of Vernik and Nur (1992) and Kenter et al. (2007) to study the acoustic 
behavior of mixed carbonate-volcaniclastic sedimentary rocks. We investigated and modeled the relation between carbonate fraction, volcaniclastic material (predominantly igneous minerals and minor clay), and porosity at effective stresses to $10 \mathrm{MPa}$. In addition, we compared and evaluated the variations in velocity, density, and porosity between the discrete sample set, core-log data, and downhole logging data.

\section{Tahiti geology and core lithology}

Tahiti is the largest of the Society Islands in French Polynesia and is composed of twin shield volcanoes (Fig. F1A) that were active from $1.367 \pm 0.016$ to $0.187 \pm 0.003 \mathrm{Ma}$ (Cabioch et al., 1999). The island is surrounded by modern discontinuous fringing reefs that grade locally into a chain of barrier reefs commonly interrupted and locally enclosing a narrow lagoon. The barrier reef complex includes, from land seaward: a backreef zone that corresponds to a $1 \mathrm{~km}$ wide bay, reaching a maximum depth of $20 \mathrm{~m}$; a relatively narrow reef flat zone $(130 \mathrm{~m}$ in maximum width); and an outer-reef slope that consists of coralbuilt spurs and grooves. In the northwest, the reef foreslope gently deepens seaward to depths of $15 \mathrm{~m}$ and then steepens sharply to $50 \mathrm{~m}$ and forms an almost vertical wall between 50 and $100 \mathrm{~m}$ (Fig. F2).

Cored material shows that the reefs around Tahiti are composed of two major lithologic units: a late deglacial carbonate sequence (Unit I) and an older Pleistocene sequence (Unit II) (see the "Expedition 310 summary" chapter) (Figs. F2, F3).

Unit I is primarily composed of coralgal-microbialite frameworks (Fig. F3A) commonly interlayered with skeletal limestone and loose skeletal sediments, including coral and algal rubble and skeletal sand. The coralgal-microbialite frameworks that form the bulk of this unit are characterized by widespread development of microbialites (Fig. F3A, F3B), which locally represent the major structural and volumetric component of the reef rock. They developed within the primary cavities of the reef framework, where they generally overlie crusts of nongeniculate coralline algae (Fig. F3B). Microbialites generally comprise a suite of fabrics including two end-members represented by laminated fabrics and thrombolitic accretions; laminated fabrics generally correspond to the most abundant fabric. The late deglacial sequence at Maraa and Tiarei displays a difference in levels of volcaniclastic component, with the reef at Tiarei containing a greater volumetric component (Fig. F3C-F3F). This can be observed in the core and downhole magnetic susceptibility logs and quantified by mineralogical analyses.

Lithologic Unit II is a coralgal framework interbedded with skeletal grainstone to packstone rich in volcanic grains (Fig. F3G, F3H). Coralgal frameworks exhibit evidence of diagenetic overprints, including the alteration of coral skeletons and the occurrence of solution cavities. Large solution cavities display yellow and brown to reddish brown staining. Some solution cavities are partly filled with sediments. Noncarbonate grains can be found as individual grains of olivine, pyroxene, and plagioclase, but millimeter-sized subrounded basaltic lithoclasts are also common (Fig. F3G, F3H).

\section{Methods and materials}

The data set analyzed in this paper is composed of downhole logging data, core logging data, and discrete measurements on core plugs from the following holes: M0005D, M0015A, and M0017A, informally called Site Maraa, and M0009B, M0009E, and M0023B, informally called Site Tiarei. Downhole logging and core logging were carried out during the offshore phase of the expedition. Core description and sampling took place during the onshore scientific party held at the University of Bremen (Germany) in February and March 2006. Discrete samples were analyzed at the Vrije Universiteit in Amsterdam (The Netherlands). All depth measurements are reported in meters below seafloor or noted otherwise.

\section{Velocity, density, and porosity}

Acoustic velocity, density, and porosity were measured on 79 samples drilled from the Tahiti cores. In the core laboratory 1.5 inch diameter cylindrical samples were drilled using a water-cooled diamond coring drill. Samples were taken in the horizontal direction at an approximate resolution of one per 1.5 $\mathrm{m}$ core section. Although sufficient for our purposes, the sampling was not ideal because of the small core diameter $(6.7 \mathrm{~cm})$ with respect to the sample diameter $(3.81 \mathrm{~cm})$, which limited sampling locations. Therefore, the downhole representation of physical properties might be limited. Sample ends were ground flat and parallel to within $0.01 \mathrm{~mm}$. Following these measurements, samples were saturated with deaired brine $(35 \% \mathrm{NaCl})$ by storing them in a vacuum for $72 \mathrm{~h}$. Ultrasonic $P$-wave $\left(V_{\mathrm{P}}\right)$ and $S$-wave $\left(V_{S}\right)$ velocities were measured as a function of pressure. A single $P$-wave and two $S$-wave velocities were measured with a transducer arrangement (Verde Geoscience, Vermont, USA) that propagated the Pwave and two independent and orthogonally polar- 
ized $S$-waves $\left(V_{S} 1\right.$ and $\left.V_{S} 2\right)$ along the core axis. The experimental procedure for obtaining acoustic velocities involves measuring the one-way traveltime along the sample axis and dividing by the sample length. In the experiment, a source and receiver pair of similar crystals is selected through an ultrasonic signal selector switch. The source crystal is excited by a fast rise-time electrical voltage pulse, which produces an ultrasonic pulse with a $\sim \mathrm{MHz}$ frequency. The arrival time is picked when the signal exceeds a threshold voltage equal to $3 \%$ of the overall peak to peak amplitude of the first three half-cycles of the signal. Precision of the velocity measurement in lowporosity carbonates is within $\sim 0.5 \%$ (Kenter et al., 1997a). Ultrasonic measurements were conducted at five effective stresses $(\mathrm{Pe})$ that ranged from 0 to 10 $\mathrm{MPa}$. Common values for confining pressures were $0,2.5,5,7.5$, and $10 \mathrm{MPa}$. Because pore pressure is kept constant at $0 \mathrm{MPa}$, confining pressures represent effective pressures. Following the acoustic measurements, dry $\left(\rho_{d}\right)$ and wet $\left(\rho_{w}\right)$ bulk densities were calculated from dry and wet weights and measured cylinder volumes. Grain densities $\left(\rho_{g}\right)$ were measured using a Micromeritics AccuPyc 1330 helium pycnometer. Total porosity $(\phi)$ was calculated from dry and grain density. More detailed procedures are described by Kenter and Ivanov (1995).

Shipboard discrete measurements of $P$-wave velocity were made using a $P$-wave sensor (PWS3) on a modified Hamilton frame velocimeter (Boyce, 1976). The PWS3 system uses a vertically oriented transducer pair capable of measuring sample cubes or cylinders. An acoustic signal of $500 \mathrm{kHz}$ was transmitted and received by the two transducers. First-arrival waveforms from samples in which the signal was weak were manually picked. Measurements were performed on brine-saturated samples $(35 \% 0 \mathrm{NaCl})$ at ambient pressure.

Core acoustic velocity, gamma density, and magnetic susceptibility were measured using a multisensor core logger (MSCL; Geotek Ltd.). Transverse $P$-wave velocity was measured using two $P$-wave transducers aligned perpendicular to the core axis with $P$-waves passing through the core horizontally (in whole-core setup). A $P$-wave pulse centered on $320 \mathrm{kHz}$ frequency is transmitted through the core. The traveltime of the acoustic signal divided by the core thickness presents the acoustic velocity. Sensors were calibrated against a tube filled with synthetic brine $(35 \%$ o $\mathrm{NaCl})$. Gamma density is measured by determining the attenuation of gamma rays (from a small

${ }^{137} \mathrm{Cs}$ source [10 millicurie; $0.662 \mathrm{MeV}$ energy]) that pass through the cores and is used to estimate bulk density. The degree of attenuation is proportional to the electron density in the gamma path. Attenuation measurements were calibrated against an aluminum cylinder with varying thicknesses of known density. Porosity is converted from the density curve by making use of a constant grain density for carbonate of $2.718 \mathrm{~g} / \mathrm{cm}^{3}$ (Mavko et al., 1998). Whole-core magnetic susceptibility was measured on the MSCL using a Bartington MS2 meter coupled to a MS2C sensor coil with a coil diameter of $88 \mathrm{~mm}$, operating at a frequency of $565 \mathrm{~Hz}$. Measurement spacing interval was set to $1 \mathrm{~cm}$ for all three sensors.

Sonic velocity was measured with a 2PSA-1000 sonic probe (Mountsopris Ltd.). The tool was calibrated by the manufacturer. The measurement spacing interval was set to $0.15 \mathrm{~m}$. No nuclear tools for measuring density were deployed during Expedition 310 because of environmental constraints. Further information regarding shipboard measurements of discrete samples, downhole logging, and core logging are described in detail in the "Expedition 310 Summary" chapter.

\section{Mineralogic content}

Mineralogic content was measured using thermogravimetric analysis (TGA) using a TGA-601. The thermogravimetric analyzer measures weight loss as a function of temperature. Weight loss of 1-2 g of sample material is measured under increasing temperature. Temperature, temperature rate, and atmosphere type are selected and monitored during five continuous weight-loss steps. In the first stage, under an oxygen atmosphere, the decomposition of organic matter is detected. In the second stage, under a nitrogen atmosphere, the decomposition of carbonate is measured. Temperature steps included $25^{\circ}-105^{\circ} \mathrm{C}$ (moisture), $105^{\circ}-480^{\circ} \mathrm{C}$ (organic matter), $480^{\circ}-600^{\circ} \mathrm{C}$ (hydroxyl groups), $600^{\circ}-875^{\circ} \mathrm{C}$, and $875^{\circ}-1000^{\circ} \mathrm{C}$ (carbonate). The leftover ash residue represents the mineral fraction that is not combusted below $1000^{\circ} \mathrm{C}$. Precision is within $3 \%$ depending on sediment origin (Konert, unpubl. data).

\section{Petrography}

For petrographic study, all plug ends were selected to reveal the sediment fabric and diagenetic features. Plug ends were impregnated (Dickson, 1965) with epoxy, and thin sections were cut parallel to the longitudinal axis. Thin sections were studied under plane-polarized light on a Zeiss optical microscope. 


\section{Results}

\section{Acoustic velocity, density, and porosity}

\section{Laboratory data}

Cross-plots of discrete measurements of $P$-wave velocity versus porosity and density for shipboard and laboratory samples are shown in Figure F4. The Tahiti samples have a narrow range in velocities. $P$ wave velocity of the laboratory samples varies between 2900 and $5000 \mathrm{~m} / \mathrm{s}$, and $S$-wave velocity varies between 1700 and $2850 \mathrm{~m} / \mathrm{s}$ (Table T1). The $V_{\mathrm{p}} / V_{\mathrm{S}}$ ratio varies between 1.74 and 2.11 , with an average of 1.92. Poisson's ratio varies between 0.21 and 0.40 , with an average of 0.31 . Porosity ranges from $1 \%$ to $35 \%$, and bulk density ranges between 1.94 and 2.54 $\mathrm{g} / \mathrm{cm}^{3}$ for saturated samples. Grain density values are between 2.58 and $3.10 \mathrm{~g} / \mathrm{cm}^{3}\left(\right.$ mean $\left.=2.88 \mathrm{~g} / \mathrm{cm}^{3}\right)$. Generally, velocities display a nearly linear decrease with increasing porosity and an increase with increasing density (Fig. F4). The scatter in velocity of samples with the same porosity can be as much as $1000 \mathrm{~m} / \mathrm{s}$ for $P$-wave velocity and $600 \mathrm{~m} / \mathrm{s}$ for $S$-wave velocity. The mean percentage deviation of the averaged orthogonal polarized $S$-waves for the samples is $1 \%$ (mean absolute deviation $=30 \mathrm{~m} / \mathrm{s}, \sigma=35 \mathrm{~m} / \mathrm{s}$ ). To assess the errors associated with measurement, the standard deviations of ultrasonic velocities were estimated by error propagation. The ends of the samples are flattened within $0.01 \mathrm{~mm}$. When the length is repeatedly measured, no significant variability is observed, so we consider the length error free. The precision of the measured velocities is within 3\%. We estimate the standard deviation of the density to be within $0.5 \%$. The estimated standard deviations $(\sigma)$ are as follows: $\sigma\left(V_{\mathrm{P}}\right)=9 \mathrm{~m} / \mathrm{s}, \sigma\left(V_{\mathrm{S}}\right)=5 \mathrm{~m} / \mathrm{s}$, and $\sigma$ $\left(\rho_{\mathrm{w}}\right)=0.006 \mathrm{~g} / \mathrm{cm}^{3}$.

\section{Core measurements and downhole logs}

Physical properties as a function of depth for three holes are plotted in Figure F5A-F5C along with the same physical properties determined from the discrete shipboard (open triangles) and laboratory (open rectangles) measurements. What is most obvious is that discrete velocity measurements do not coincide with core measurements and downhole logs. Measurements on the core plugs are offset positively from core measurements, whereas the downhole logging data show lower velocities compared to core measurements. Density and porosity measurements of discrete samples are in good agreement with core measurements. Differences between discrete velocity measurements and core and downhole logging data are as much as 800 and $1200 \mathrm{~m} / \mathrm{s}$ maximum for the lithologic Unit I samples, respectively. Discrete measurements of Unit II samples show much smaller offsets, as much as 400 and $800 \mathrm{~m} / \mathrm{s}$ maximum, respectively, for core measurements and downhole derived data (Fig. F5C).

Figure F6 shows cross-plots of velocity and porosity from MSCL core logging data and discrete plug measurements for Holes M0005D, M0009B, M0009E, M0015A, and M0017A, along with the time-average and Raymer equations for a matrix velocity of calcite. Discrete laboratory measurements (open triangles) show specific porosity-velocity relationships. Hole M0005D samples vary as much as $1000 \mathrm{~m} / \mathrm{s}$ at a given porosity and have a trend that falls on the Wyllie velocity transform. Data from Holes M0009B, M0009E, and M0015A show small variations $(<500$ $\mathrm{m} / \mathrm{s}$ ) and follow the predicted trend of the Raymer velocity transform. Finally, Hole M0017A and M0023B data follow the predicted trend of the Raymer transform below $20 \%$ porosity and are positively offset with respect to the velocity transforms over $20 \%$ porosity. In general, $P$-wave velocities of different samples show a nonlinear concave-upward trend similar to the velocity equations, rather than the linear relationship visible in MSCL data. MSCL data generally follow the predicted Wyllie trend for most boreholes, but the variation at a given porosity, locally $>1.5 \mathrm{~km} / \mathrm{s}$, is not explained by the velocity transform. No clear difference is observed among the trends at the various boreholes. Finally, the discrete shipboard velocity measurements (open rectangles) are all positively offset from laboratory and MSCL data points. This offset increases toward higher porosity (as much as $1500 \mathrm{~m} / \mathrm{s}$ ).

\section{Petrography and insoluble residue}

The mixed siliciclastic-carbonate samples were divided into groups based on petrographic observations of textural factors (e.g., Vernik and Nur, 1992; Kenter et al., 2007) and geochemically segregated according to content of carbonate and noncarbonate fractions (Table T1). These petrophysical groups and their associated characteristics include: (1) Holocene volcaniclastic-poor carbonates (Maraa Site, lithologic Unit I), (2) Holocene volcaniclastic-rich carbonates (Tiarei Site, Unit I), and (3) Pleistocene reefal-volcaniclastic carbonates (Maraa Site, Unit II).

For the Unit I samples from Maraa, mean carbonate content is $95 \%$ (minimum $=90 \%$; maximum $=96 \%$ ). Samples are dominated by coralgal-microbialite framework with little contamination from volcaniclastic input. Unit I samples from Tiarei display mean carbonate content of $83 \%$ (minimum $=69 \%$; maximum $=96 \%$ ). The samples are also mostly composed of coralgal-microbialite framework but with variable amounts of volcaniclastic grains dispersed through the matrix. The fraction of noncarbonate 
content may be as much as $31 \%$. Volcanic grains are predominantly silt- to medium sand-sized grains of olivine, pyroxene, and plagioclase. Organic matter and minerals containing hydroxyl groups (clays) are present in fractions up to $9 \%$. Unit II samples from Maraa also show coralgal framework along with moderately cemented skeletal-volcaniclastic sand showing clear isopachous rims of early marine cement ( 100 $\mu \mathrm{m}$ thick). Marine cements have bladed and fibrous morphologies. Mean carbonate content is $90 \%($ minimum $=79 \%$; maximum $=97 \%)$.

\section{Discussion}

Acoustic velocity is a complex result of several parameters that together control range and absolute values of velocity in sedimentary rocks. In the next sections we discuss the controlling factors and compare their significance in controlling the acoustic properties.

\section{Mineralogic composition}

Pure carbonates are characterized by the lack of clay or siliciclastic content and are mostly produced and deposited on the top or on the slope of isolated or detached carbonate platforms, which have no hinterland as a source of terrigenous material (Wilson, 1975; Eberli, 1991). They consist of $>95 \%$ of the carbonate minerals calcite (low- and high-Mg), dolomite, and aragonite. The Tahiti reef system is unusual because a large part of the framework is not only made up by in situ coral colonies and skeletal sand but also, and in fact volumetrically most abundant, by microbialite. These reefal microbialites correspond to a late stage of encrustation of the dead parts of coral colonies or, more commonly, of related encrusting organisms (red algae and foraminifers), thus forming surface crusts (Camoin et al., 1999). The microbialites consist of laminated crusts and clotted micritic masses and are characterized by a suite of characteristic fabrics. Their growth forms, great variations in thickness, lateral persistence, and small-scale internal structures allow them to be interpreted as bioaccretionary features (Camoin et al., 1999). They form crusts on average a few centimeters thick, locally up to $10 \mathrm{~cm}$ thick, that comprise stacked generations of accretions displaying a wide range of growth forms ranging from irregular domes and bulbs to columnar.

Significant in Tahiti is that the carbonate reefs are contaminated with terrigeneous input (volcaniclastic in origin) from the island. The microbialites in particular are capable of withstanding terrigeneous influx during accumulation and trapped extraneous particles within the microbially mediated precipita- tion of micrite (Camoin et al., 1999). The abundance of volcaniclastic material probably reflects a depositional input signal which was influenced by (1) the discharge of the Tiarei river supplying the Tiarei site carbonate samples with dispersed fine to medium sand-sized volcaniclastic grains through the matrix, versus a "clean" reefal system at Maraa with very little insoluble residue; and (2) well-rounded sand- to small pebble-sized volcaniclastic grains found throughout the Pleistocene sequence. This last may point to a different carbonate platform geometry compared to the Holocene sequence, with different hydrodynamic and sediment supply conditions that favored the transport and abrasion of coarse volcaniclastic grains, which were subsequently incorporated in the bioclastic grainstone.

Figure F7A and F7B are cross-plots illustrating the clear relationship between insoluble residue and sonic velocity. Samples high in carbonate content plot toward the higher velocity values. At values $<8 \%$ noncarbonate content, velocities are $>4500 \mathrm{~m} / \mathrm{s}$. Minor amounts of noncarbonate material, clay, and/or quartz silt/sand can dramatically change acoustic velocities (Kenter et al., 1997b). Clay minerals and organic material have a negative effect on acoustic velocity (Stafleu et al., 1994). In the Tahiti samples the fraction of clay minerals and organic material present may be as high as $8.6 \mathrm{wt} \%$ and as such affect the acoustic velocity, causing negative deviations from the general trends. For Unit I, Site Maraa mean noncarbonate content is $5 \%$, whereas for Site Tiarei mean noncarbonate content is $17 \%$. This results in an overall average decrease in $P$-wave velocity of 130 $\mathrm{m} / \mathrm{s}$.

\section{Rock texture, diagenesis, and Poisson's ratios}

Diagenetic overprint is one of the most prominent factors during maturation of carbonate rocks. Carbonate minerals are metastable and prone to rapid and intense modifications that alter the elastic properties of the rock and, therefore, the acoustic velocity. In particular, cementation and dissolution processes continuously modify the pore structure to create or destroy porosity. Unit II samples are different from Unit I samples in two respects. The first is the texture of the sediment. Whereas Unit I samples consist of coralgal-microbialite framework which forms one massive structure, Unit II samples are dominantly arenitic in nature. The granular texture may have originated with wave abrasion of the Unit II reef system, and samples are relatively mature with dominant subrounded grains. The texture would be classified as granular following Kenter et al. (2007). Secondly, grains in Unit II samples are lined by 
isopachous rims of early marine cement. Touching cement is known to have a positive effect on acoustic velocity. For example, Kenter et al. (1997a) discuss a data set of immature skeletal grainstones and show that a $12 \%$ increase in cement (12\% decrease in porosity, no change in grain size) correlates to an increase of $P$-wave velocity of $790 \mathrm{~m} / \mathrm{s}$ (33\%), $S$-wave velocity of $525 \mathrm{~m} / \mathrm{s}(45 \%)$, and decrease in Poisson's ratio of $0.025(7.5 \%)$.

Figure F8 is a cross-plot of $P$-wave velocity versus Poisson's ratio with a number of mixed carbonateclastic literature data sets (Limburg Quarry, Kenter et al., 1997a; Florida Keys, Anselmetti et al., 1997; Last Chance Canyon, Kenter et al., 1997b) plotted along with the Tahiti sample set. The individual sample sets data are discriminated for carbonate content. Poisson's ratio, which is a specific ratio of $P$-wave over $S$-wave velocity, is defined as the ratio of transverse contraction over longitudinal stretching in a stretched bar and is defined as minus to compensate for normal materials. Poisson's ratio influences the speed of propagation and reflection of stress waves and is important in predicting the nature of rocks (Rafavich et al., 1984). Poisson's ratio (v) is easily deduced from $V_{\mathrm{p}}$ and $V_{\mathrm{S}}$ directly through the following equation (Domenico, 1995; Mavko et al., 1998, p. 52):

$$
v=\left(V_{\mathrm{P}}^{2}-2 V_{\mathrm{S}}^{2}\right) / 2\left(V_{\mathrm{P}}^{2}-V_{\mathrm{S}}^{2}\right) .
$$

In this application, Poisson's ratio can be interpreted to represent a measure of the material response to applied stress, which is directly related to the nature of the mineral and texture makeup of a rock. This procedure has been used in the past by various authors (Ostrander, 1984; Rafavich et al., 1984; Shuey, 1985; Verm and Hilterman, 1995; Berg, 1997; Ozel et al., 1999) as a method to express the dependency of pore type and mineralogy.

From the cross-plot (Fig. F8) a number of observations can be made. The Limburg Quarry and Florida Keys $\left(>0.92 \% \mathrm{CaCO}_{3}\right)$ data groups are situated in the upper left quadrant of the plot, corresponding to high Poisson's ratios at relatively low $P$-wave velocities, typical for clean, immature carbonate samples. The Tahiti sample group is situated at $\sim 4500 \mathrm{~m} / \mathrm{s} P$ wave velocity with the samples with $>92 \%$ carbonate content toward the higher velocity values. The samples with $>8 \%$ noncarbonate material are found toward velocities of $<4500 \mathrm{~m} / \mathrm{s}$. Poisson's ratios are relatively high, $\sim 0.32$ on average. The Last Chance Canyon data set displays a similar separation at $\sim 5500 \mathrm{~m} / \mathrm{s}$. In addition, samples rich in clay are discriminated and correspond to $P$-wave velocity values dominantly $<4500 \mathrm{~m} / \mathrm{s}$. The Last Chance Canyon sample set, however, shows much lower Poisson's ratios, grouped around 0.25 . These rock samples have undergone significantly more diagenetic alteration (cf. Kenter et al., 1997b). Quartz graywackes and quartz-rich wackestones exhibit sutured grain contacts formed as a result of pressure solution during burial. In addition, biomoldic porosity is partially occluded by columnar and blocky calcite cements that postdate the pressure solution and are therefore a product of burial diagenesis. After burial diagenesis, selective vuggy dissolution created the present-day porosity as a result of dissolution and precipitation in oxygenated meteoric near-surface groundwaters. During burial diagenesis $S$-wave properties profit significantly more than $P$-wave properties from compaction and cementation. The frame stiffens, with higher $S$-wave velocities as a result, hence the lower Poisson's ratios. From the cross-plot one can conclude that the main parameter affecting the acoustic behavior of the samples is the burial diagenesis and presence of noncarbonate material.

\section{Velocity transforms}

Popular velocity transforms for density to velocity and porosity to velocity transformations are the Gardner transform (Gardner et al., 1974); the Wyllie et al. (1956) equation, or time-average equation; and the modification of the time-average equation of Raymer et al. (1980). All are empirical relationships. In general, experimental data sets rarely follow these models in great detail, and therefore the equations are used for comparison. Figure F6 shows cross-plots of porosity versus $P$-wave velocity derived from corelog data from all sites. Discrete laboratory measurements are superimposed. Time-average equations for solid-phase velocities of $6.5 \mathrm{~km} / \mathrm{s}$ (calcite) and Raymer equations are indicated by a solid line and a dashed line, respectively. Whereas the velocity transforms describe a slightly concave-upward shape, the measured core logging data follow a linear equation and deviate as much as $1000 \mathrm{~m} / \mathrm{s}$ at a given porosity (Fig. F6). Figure F9 shows cross-plots of acoustic velocity versus porosity (A) and versus density (B), along with velocity-porosity transforms of Wyllie et al. (1956) for various matrix velocities, and (B) Gardner's equation (1974) for limestone and Anselmetti and Eberli equation (1993) undifferentiated for mineralogy. Discrete measurements for the Tahiti data set are positively offset with respect to the Gardner limestone equation. The data set follows the Anselmetti and Eberli (1993) equation more closely (Fig. F9B). The Wyllie time-average equation gives a good approximation for samples with up to $18 \%$ porosity; however, above this it is clear that with increasing porosity the velocity of the discrete measurements 
shows a positive deviation from the velocity transforms. The same holds for decreasing density. One possible explanation may be the presence of the volcaniclastic minerals of olivine, pyroxene, and plagioclase with respective matrix velocities of 8480,7850 , and $6300 \mathrm{~m} / \mathrm{s}$ (Carmichael, 1989), which are higher than the matrix velocity of calcite $(6530 \mathrm{~m} / \mathrm{s})$.

A linear regression was used to calculate velocity-porosity transforms that predict sonic acoustic from porosity and carbonate content or at different levels of volcaniclastic contamination. Similar to the velocity-porosity transforms calculated for siliciclastics by Vernik and Nur (1992), the velocity-porosity relation for a given mineralogic composition is a linear equation. At a fixed porosity, the velocity-mineralogy relation is also a linear function and has a similar variation as the velocity-porosity equation for the range in porosity between $0 \%$ and 30\% (Fig. F7A). Subsequently, in this porosity range and for this limited data set the effect of carbonate content on acoustic behavior is comparable to that of porosity. At zero porosity, the clean carbonates (Site Maraa) have $P$ wave velocities of $4.9 \mathrm{~km} / \mathrm{s}$ and are as much as 130 $\mathrm{m} / \mathrm{s}$ higher than those for the volcaniclastic-rich samples (Site Tiarei). With increasing porosity, this difference remains fairly constant as the slopes of the velocity-porosity relation are similar $(200 \mathrm{~m} / \mathrm{s}$ higher diversion at $35 \%$ porosity). The intersection point of the velocity-porosity transform with the zero-porosity axis decreases with decreasing carbonate content, which may be explained by the presence of clay minerals and organic content. The slope of the velocity-porosity transform for lithologic Unit II samples (cemented mixed carbonate-volcaniclastic specimens) is steeper than that for high Unit I samples. For $P$-wave velocities this gradient is $5.14 \mathrm{~km} / \mathrm{s}$ per porosity unit. This is a more common value for mature carbonate rocks and has been documented in previously published data (e.g., Kenter and Ivanov, 1995; Kenter et al., 1997b).

\section{Comparison with core measurements and downhole logging data}

Figure F5 shows the comparison between downhole logging velocity, core logging velocity, and $P$-wave velocity in minicores under confining pressure. Sonic velocities are slower than the discrete measurements with the larger excursions toward the lower velocities. For the Tiarei samples there is a poor correlation between log velocity and discrete velocity measured under effective pressure. Log velocities have corresponding laboratory velocities from 5\% to $15 \%$ higher. Similar observations can be made from the correlation of log velocity with discrete velocity in lithologic Unit I at Site Maraa. Unit II samples from Maraa, however, show much closer agreement between downhole data and laboratory measurements (Fig. F5A at 21R). Discrete measurements of Unit I experience larger differences than Unit II samples (cf. Fig. F5A-F5C).

The progressive deviation of discrete velocity from log velocity toward higher values is probably primarily related to the "selective" sampling of more competent (and therefore "faster") rock fabrics during coring operations. In addition, there is a $\pm 2 \mathrm{~m}$ uncertainty between the methods used to calculate "log depth" and "core (pipe) depth." Second, one of the most important effects is the introduction of velocity dispersion: seismic velocities increase with increasing frequency (Paillet and Cheng, 1991; Mavko et al., 1998). Discrete measurements of velocity are performed using ultrasonic frequencies (1 MHz), whereas the sonic log uses $10 \mathrm{kHz}$ frequencies. Third, the quality of the sonic log is closely related to the borehole's diameter and shape. Abundant cycle skipping in the sonic log raw data and poor hole quality (i.e., presence of coring-induced fractures or other damage to the wall of the borehole; see caliper log in the "Expedition 310 summary" chapter) reduce the quality of the sonic log (Bourbié et al., 1987). Fourth, the scale of lithologic, and therefore petrophysical, alternations within the core is critical compared to the sampling interval of the sonic log. Where discrete measures of velocity are only on matrix sediments, the sonic log provides an average over an interval of $1 \mathrm{ft}(\sim 31 \mathrm{~cm})$ in which velocity is averaged over large primary pores containing seawater $(\sim 1535$ $\mathrm{m} / \mathrm{s}$ ) and rock. These effects should be considered when comparing acoustic data sets from a variety of sources.

\section{Conclusions}

Measurements of the petrophysical properties, quantitative mineralogic composition, observations on the texture, and subsequent subdivision into petrophysical groups of 79 rock specimens of young Pleistocene and Holocene sediments have important implications for the understanding of the acoustic behavior of mixed carbonate-volcaniclastic rocks.

Primary control on the acoustic properties is exerted by porosity. The remaining variation in acoustic properties is explained by the mineralogical and textural parameters: the presence of volcaniclastic material and diagenetic alteration. No clear linear thresholds are defined; however, a general trend is that insoluble residue and fringing cement have opposite and overlapping effects on acoustic properties. Where clay minerals and organic material have a negative effect on acoustic velocity, introduction of 
magmatic minerals in the matrix results in positive deviation in velocity from general trends. Within carbonate-lithoclastic sand the amount of fringing cement controls acoustic velocity.

Common velocity-porosity transforms by Wyllie et al. (1956) and Raymer et al. (1980) only imperfectly explain the observed relationship between velocity and porosity in the data set. Clean carbonate samples generally fall onto Wyllie's curve; magmatic minerals cause positive velocity deviations. Gardner's experimental curve underestimates the velocity-density relation. Poisson's ratio is introduced as a tool to identify maturation overprint of various sample sets from acoustic data alone. High Poisson's ratios ( 0.32) correspond to immature data sets, whereas data groups which experienced burial diagenesis display lower Poisson's ratios ( 0.25).

These findings suggest a more complicated relationship for mixed carbonate-volcaniclastics than that earlier documented for pure siliciclastics. Reasons for this may be the mineral mixing and the property of carbonate minerals to form more different intercrystalline boundaries under diagenetic alteration. The results of this quantitative analysis may have important implications for the prediction of porosity from acoustic velocities in similar mixtures of sediment. In addition, they may provide a direct link between acoustic properties and the primary depositional system and sequence stratigraphic history of the studied interval thereby connecting geology and seismic.

\section{Acknowledgments}

Samples and data were provided by the Integrated Ocean Drilling Program (IODP). Shipboard participation in Expedition 310 for K. Verwer was made possible by a grant from the Dutch Science Foundation-Field of Earth and Life Sciences (Raymond Schorno). Gilbert Camoin (Aix en Provence, France), Yasu Iryu (Sendai, Japan), Dave McInroy (Edinburgh, United Kingdom), and the Expedition 310 Scientists are acknowledged for stimulating discussions. Jenny Inwood (Leicester, United Kingdom) is thanked for petrophysical measurements. Dr. Hirono (Osaka, Japan) is thanked for a constructive review. The laboratory for sedimentary geology and the workshop of the Faculty of Earth and Life Sciences and Johan de Lange (Vrije Universiteit) were vital to the research.

\section{References}

Anselmetti, F.S., and Eberli, G.P., 1993. Controls on sonic velocity in carbonates. Pure Appl. Geophys., 141(2-4):287-323. doi:10.1007/BF00998333
Anselmetti, F.S., von Salis, G.A., Cunningham, K.J., and Eberli, G.P., 1997. Acoustic properties of Neogene carbonates and siliciclastics from the subsurface of the Florida Keys: implications for seismic reflectivity. Mar. Geol., 144(1-3):9-31. doi:10.1016/S0025-

3227(97)00081-9

Berg, E., 1997. 4C-2D or 3D sea bed seismic methodology. Proc. 11R Forum Acquis., Process. Interpret. Mar. Seism. Data, 1274-1282.

Bourbié, T., Coussy, O., and Zinszner, B., 1987. Acoustics of Porous Media: Paris (Ed. Technip.).

Boyce, R.E., 1976. Definitions and laboratory techniques of compressional sound velocity parameters and wet-water content, wet-bulk density, and porosity parameters by gravimetric and gamma-ray attenuation techniques. In Schlanger, S.O., Jackson, E.D., et al., Init. Repts. DSDP, 33: Washington, DC (U.S. Govt. Printing Office), 931-958. doi:10.2973/dsdp.proc.33.1976

Cabioch, G., Camoin, G.F., and Montaggioni, L.F., 1999. Postglacial growth history of a French Polynesian barrier reef tract, Tahiti, central Pacific. Sedimentology, 46(6):985-1000. doi:10.1046/j.1365-

3091.1999.00254.x

Camoin, G.F., Gautret, P., Montaggioni, L.F., and Cabioch, G., 1999. Nature and environmental significance of microbialites in Quaternary reefs: the Tahiti paradox. Sediment. Geol., 126(1-4):271-304. doi:10.1016/S00370738(99)00045-7

Camoin, G.F., Iryu, Y., McInroy, D., and the Expedition 310 Project Team, 2005. The last deglacial sea level rise in the South Pacific: offshore drilling in Tahiti (French Polynesia). IODP Sci. Prosp., 310. doi:10.2204/ iodp.sp.310.2005

Carmichael, R.S., 1989. Practical Handbook of Physical Properties of Rocks and Minerals: Boca Raton, FL (CRC Press).

Cunningham, K.J., Locker, S.D., Hine, A.C., Bukry, D., Barron, J.A., and Guertin, L.A., 2003. Interplay of late Cenozoic siliciclastic supply and carbonate response on the Southeast Florida Platform. J. Sediment. Res., 73(1):31-46. doi:10.1306/062402730031

Dickson, J.A.D., 1965. A modified staining technique for carbonates in thin section. Nature (London, U. K.), 205(4971):587. doi:10.1038/205587a0

Domenico, N., 1995. Poisson's ratio-an interdisciplinary link? Leading Edge, 14:983-986.

Dunbar, G.B., and Dickens, G.R., 2003. Massive siliciclastic discharge to slopes of the Great Barrier Reef platform during sea-level transgression: constraints from sediment cores between $15^{\circ} \mathrm{S}$ and $16^{\circ} \mathrm{S}$ latitude and possible explanations. Sediment. Geol., 162(1-2):141-158. doi:10.1016/S0037-0738(03)00216-1

Eberli, G.P., 1991. Calcareous turbidites and their relationship to sea-level fluctuations and tectonism. In Einsele, G., Werner, R., and Seilacher, A. (Eds.), Cycles and Events in Stratigraphy: Berlin (Springer Verlag), 340-359.

Gardner, G.H.F., Gardner, L.W., and Gregory, A.R., 1974. Formation velocity and density - the diagnostic basics for stratigraphic traps. Geophysics, 39(6):770-780. doi:10.1190/1.1440465 
Kenter, J.A.M., Braaksma, H., Verwer, K., and van Lanen, X.M.T., 2007. Acoustic behavior of sedimentary rocks: geological properties versus Poisson's ratios. Leading Edge, 26(4):436-444. doi:10.1190/1.2723206

Kenter, J.A.M., Bracco Gartner, G.L., and Schlager, W., 2001. Seismic models of a mixed carbonate-siliciclastic shelf margin: Permian upper San Andres Formation, Last Chance Canyon, New Mexico. Geophysics, 66(6):1744-1748. doi:10.1190/1.1487116

Kenter, J.A.M., Fouke, B.W., and Reinders, M., 1997. Effects of differential cementation on the sonic velocities of Late Cretaceous skeletal grainstones (southeastern Netherlands). J. Sediment. Res., 67:178-185.

Kenter, J.A.M., and Ivanov, M., 1995. Parameters controlling acoustic properties of carbonate and volcaniclastic sediments at Sites 866 and 869. In Winterer, E.L., Sager, W.W., Firth, J.V., and Sinton, J.M. (Eds.), Proc. ODP, Sci. Results, 143: College Station, TX (Ocean Drilling Program), 287-303. doi:10.2973/ odp.proc.sr.143.232.1995

Kenter, J.A.M., Podladchikov, F.F., Reinders, M., van der Gaast, S.J., Fouke, B.W., and Sonnenfeld, M.D., 1997. Parameters controlling sonic velocities in a mixed carbonate-siliciclastics Permian shelf-margin (upper San Andres Formation, Last Chance Canyon, New Mexico). Geophysics, 62(2):505-520. doi:10.1190/1.1444161

Mavko, G., Mukerji, T., and Dvorkin, J., 1998. The Rock Physics Handbook: Cambridge (Cambridge Univ. Press).

Ostrander, W.J., 1984. Plane-wave reflection coefficients for gas sands at non-normal angles of incidence. Geophysics, 49(10):1637-1648. doi:10.1190/1.1441571

Ozel, O., Iwasaki, T., Moriya, T., Sakai, S., Maeda, T., Piao, C., Yoshii, T., Tsukada, S., Ito, A., Suzuki, M., Yamazaki, A., and Miyamachi, H., 1999. Crustal structure of central Japan and its petrological implications. Geophys. J. Int., 138(1):257-274. doi:10.1046/j.1365246x.1999.00859.x

Paillet, F.L., and Cheng, C.H., 1991. Acoustic Waves in Boreholes: Boca Raton, FL (CRC Press).

Playford, P.E., 1980. Devonian 'Great Barrier Reef' of Canning Basin, Western Australia. AAPG Bull., 62:814-841.

Rafavich, F., Kendall, C.H.St.C., and Todd, T.P., 1984. The relationship between acoustic properties and the petrographic character of carbonate rocks. Geophysics, 49(10):1622-1636. doi:10.1190/1.1441570
Rankey, E.C., Bachtel, S.L., and Kaugmann, J., 1999. Controls on stratigraphic architecture of icehouse mixed carbonate-siliciclastic systems: a case study from the Holder Formation (Pennsylvanian, Virgilian), Sacramento Mountains, New Mexico. In Harris, P.M., Saller, A.H., and Simo, J.A. (Eds.), Advances in Carbonate Sequence Stratigraphy: Applications to Reservoirs, Outcrops, and Models. Spec. Publ.-SEPM (Soc. Sediment. Geol.), 63:127-150.

Raymer, L.L., Hunt, E.R., and Gardner, J.S., 1980. An improved sonic transit time-to-porosity transform. Trans. SPWLA 21st Annu. Log. Symp., Pap. P.

Shuey, R.T., 1985. A simplification of the Zoeppritz equations. Geophysics, 50(4):609-614. doi:10.1190/ $\mathbf{1 . 1 4 4 1 9 3 6}$

Sonnenfeld, M.D., and Cross, T.A., 1993. Volumetric partitioning and facies differentiation within the Permian upper San Andres Formations, Guadalupian Mountains, New Mexico and Texas. In Loucks, C.G., and Sarg, J.F. (Eds.), Carbonate Sequence Stratigraphy-Recent Developments and Applications. AAPG Mem., 57:435-474.

Stafleu, J., Everts, A.J.W., and Kenter, J.A.M., 1994. Seismic models of a prograding carbonate platform: Vercors, south-east France. Mar. Pet. Geol., 11(5):514-537. doi:10.1016/0264-8172(94)90065-5

Verm, R.W., and Hilterman, F.J., 1995. Lithologic colorcoded sections: the calibration of AVO crossplotting to rock properties. Leading Edge, 14(8):847-853. doi:10.1190/1.1437170

Vernik, L., and Nur, A., 1992. Petrophysical classification of siliciclastics for lithology and porosity prediction from seismic velocities. AAPG Bull., 76:1295-1309.

Verwer, K., Braaksma, H., and Kenter, J.A.M., 2008. Acoustic properties of carbonates: Effects of rock texture and implications for fluid substitution. Geophysics, 73(2):B51-B65. doi:10.1190/1.2831935

Wilson, J.L., 1975. Carbonate Facies in Geologic History: Berlin (Springer-Verlag).

Wyllie, M.R.J., Gregory, A.R., and Gardner, L.W., 1956. Elastic wave velocities in heterogeneous and porous media. Geophysics, 21(1):41-70. doi:10.1190/1.1438217

Initial receipt: 4 November 2008

Acceptance: 26 June 2009

Publication: 24 August 2009

MS 310-203 
Figure F1. A. Location map of Tahiti and Moorea, Society Islands, French Polynesia, with drilling sites. Samples are taken from cores from Site Maraa (A-A' transect) and Site Tiarei. B. DP Hunter at Site Maraa, 1 km outboard from the Recent reef system.

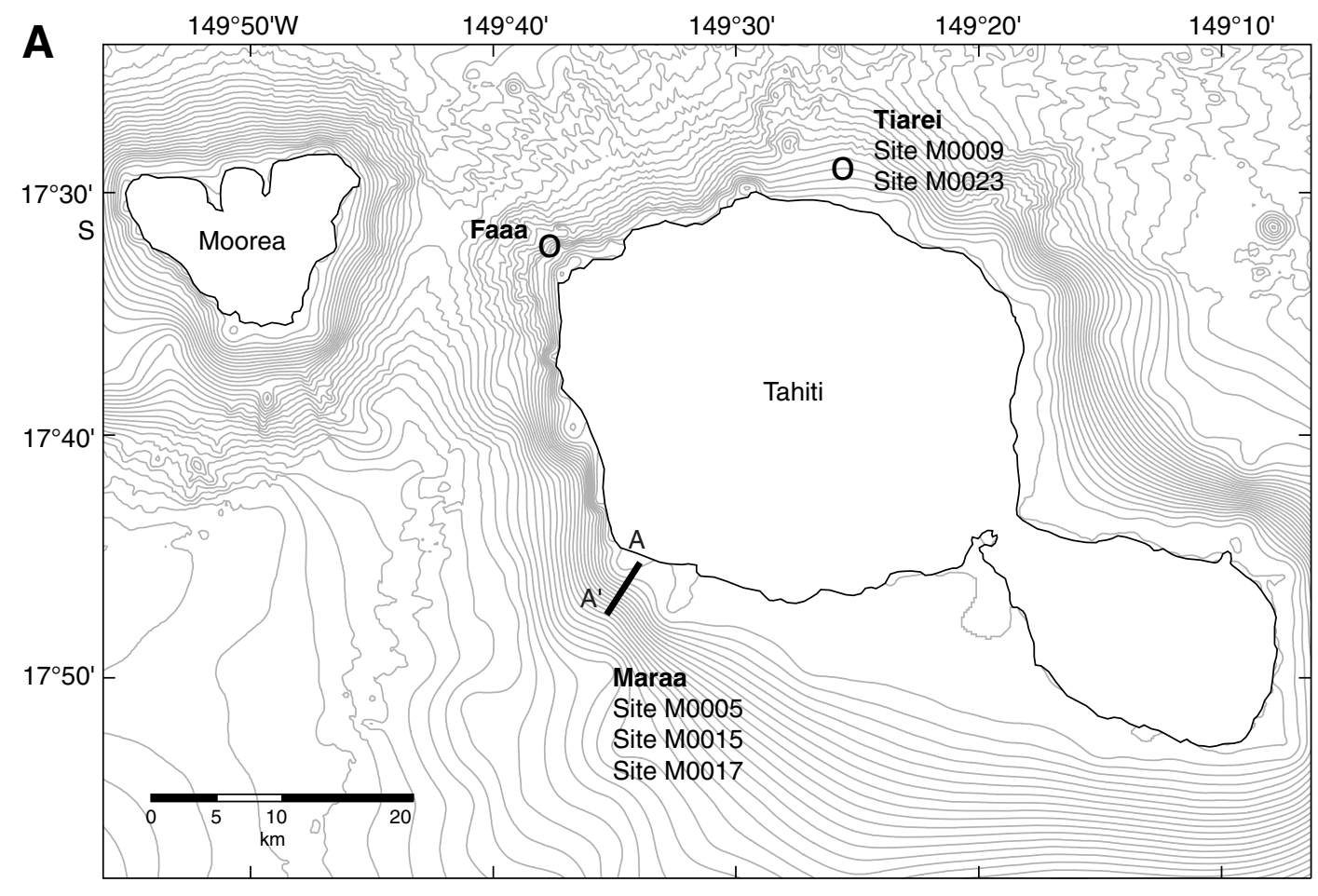

B

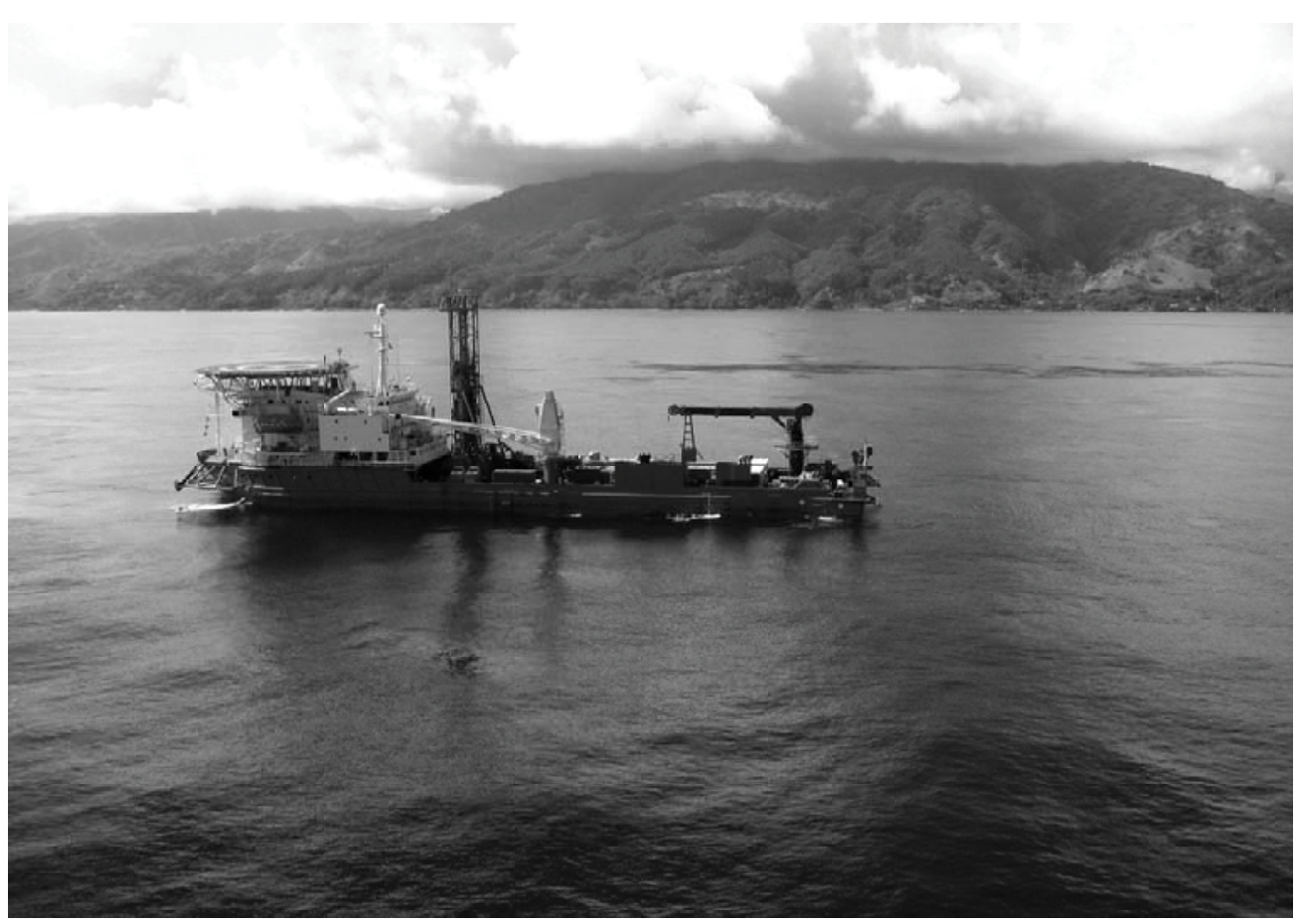


Figure F2. Lithologic cross section through Maraa transect $\left(\mathrm{A}-\mathrm{A}^{\prime}\right)$.

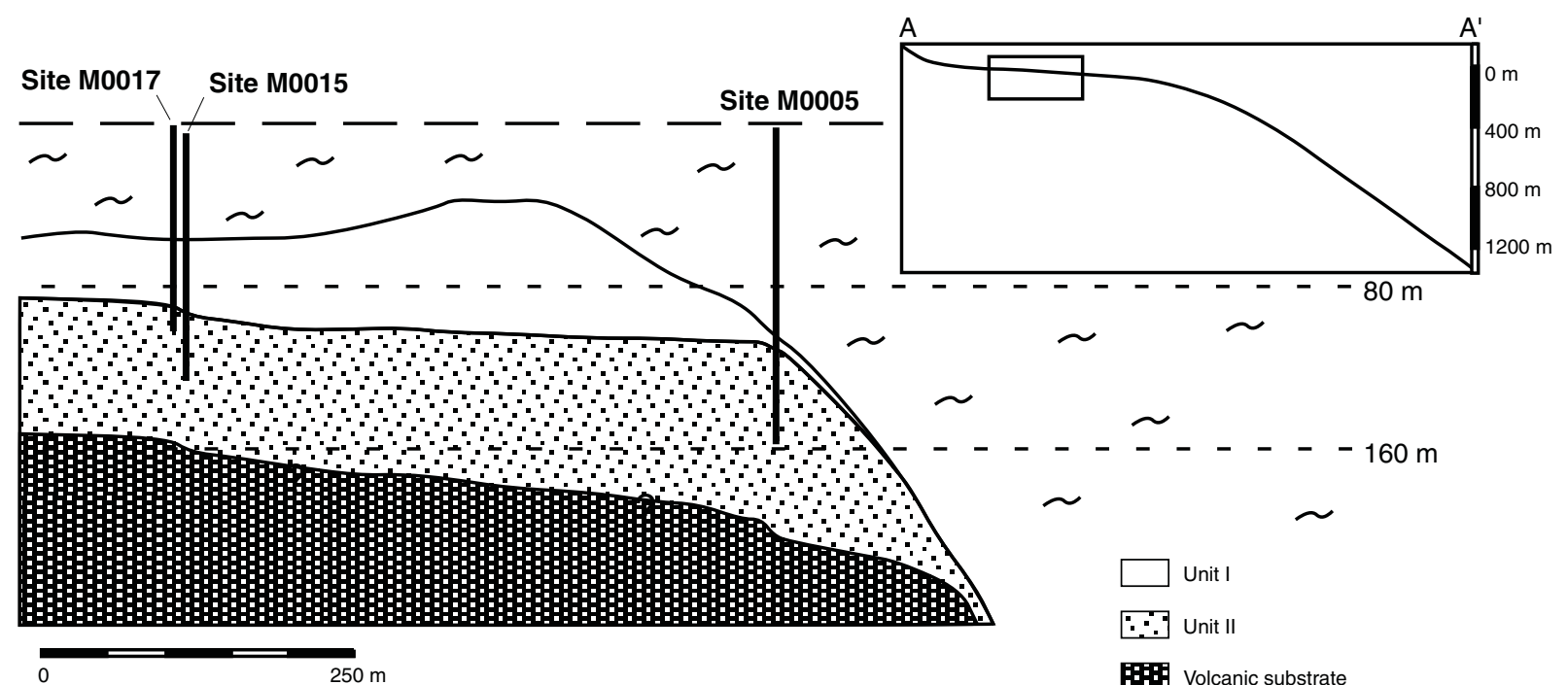


Figure F3. Photomicrographs of dominant sediment types. A, B. Lithologic Unit I Site Maraa "clean" samples showing peloidal microbialite fabric and coralgal framework with associated microbialite. A: $\phi=0.19, V_{\text {Pwet }}=$ $4642 \mathrm{~m} / \mathrm{s}, V_{\text {Swet }}=2480 \mathrm{~m} / \mathrm{s} . \mathrm{B}: \phi=0.26, V_{\text {Pwet }}=4485 \mathrm{~m} / \mathrm{s}, V_{\text {Swet }}=2392 \mathrm{~m} / \mathrm{s}$. C-F. Lithologic Unit I Site Tiarei samples showing volcaniclastic grains of olivine and pyroxene dispersed through microbialite matrix associated with coralgal framework. C: $\phi=0.19, V_{\text {Pwet }}=4554 \mathrm{~m} / \mathrm{s}, V_{\text {Swet }}=2410 \mathrm{~m} / \mathrm{s}$. D, F: $\phi=0.32, V_{\text {Pwet }}=4065 \mathrm{~m} / \mathrm{s}, V_{\text {Swet }}$ $=2124 \mathrm{~m} / \mathrm{s}$. E: $\phi=0.21, V_{\text {Pwet }}=4474 \mathrm{~m} / \mathrm{s}, V_{\text {Swet }}=2364 \mathrm{~m} / \mathrm{s}$. G, H. Lithologic Unit II Site Maraa samples showing lithoclastic-skeletal grainstone. Skeletal grains include redalgal fragments, coral fragments, micritized grains, and undifferentiated skeletal debris. Volcaniclastic grains include olivine, pyroxene and plagioclase grains, and millimeter-sized subrounded basaltic lithoclasts. Note isopachous rims of marine cement lining the granular texture. G: $\phi=0.14, V_{\text {Pwet }}=4157 \mathrm{~m} / \mathrm{s}, V_{\text {Swet }}=2237 \mathrm{~m} / \mathrm{s} . \mathrm{H}: \phi=0.16, V_{\text {Pwet }}=4324 \mathrm{~m} / \mathrm{s}, V_{\text {Swet }}=2242 \mathrm{~m} / \mathrm{s}$. (Figure shown on next page.) 
Figure F3 (continued). (Caption shown on previous page.)
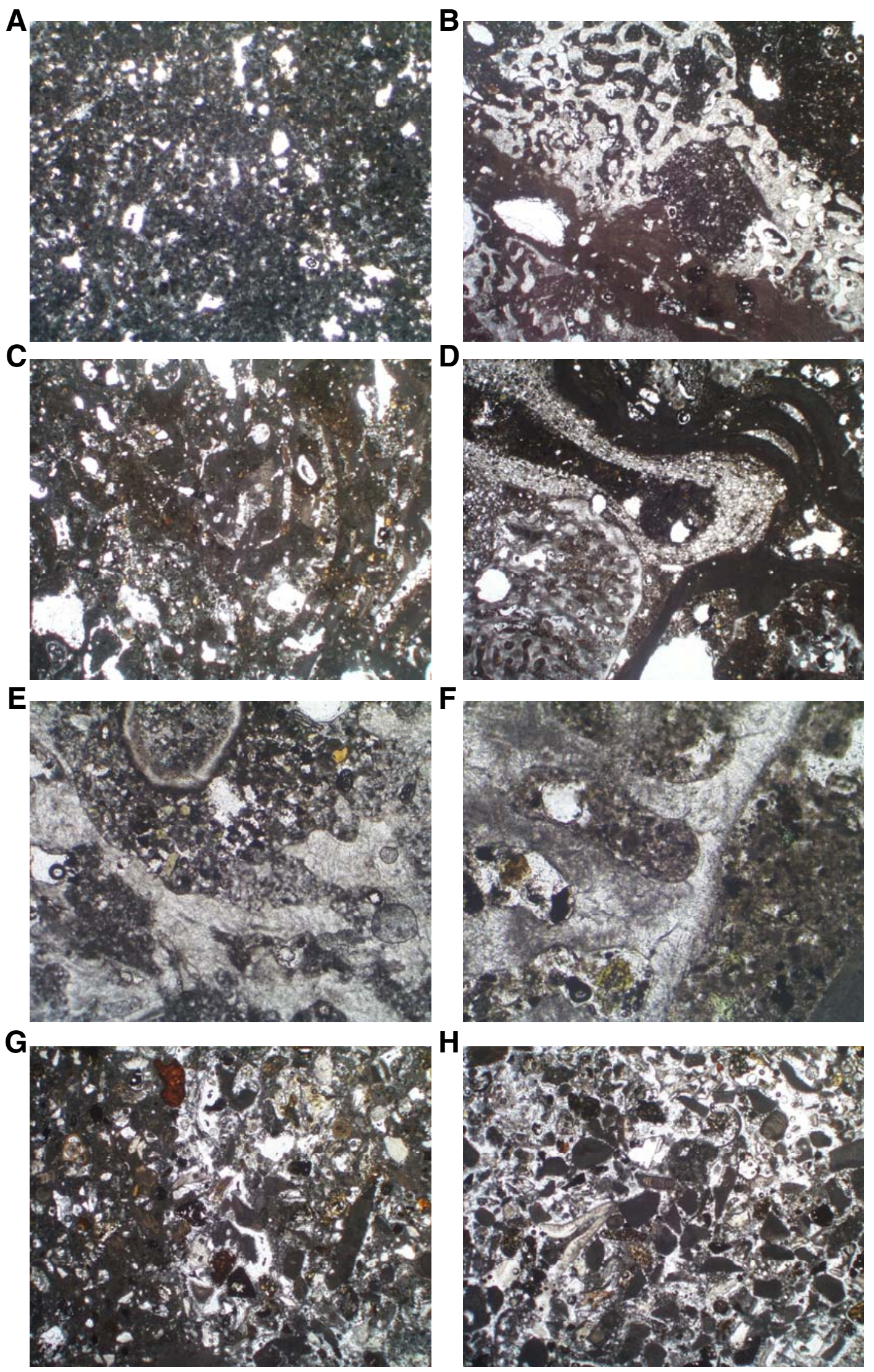
Figure F4. Velocity and porosity cross-plots. A. $P$-wave and $S$-wave velocity vs. porosity. B. $P$-wave and $S$-wave velocity vs. density. C. $V_{\mathrm{P}} / V_{\mathrm{S}}$ ratio vs. porosity. D. Poisson's ratio vs. porosity.

A
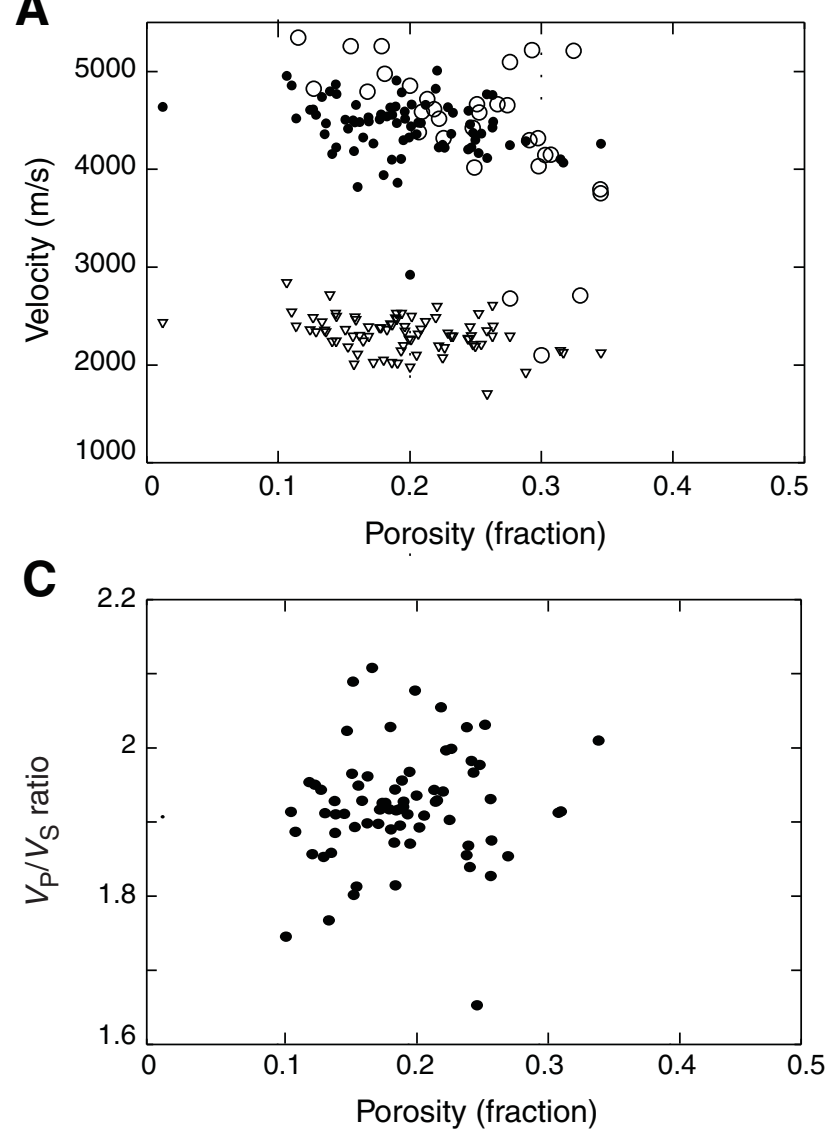
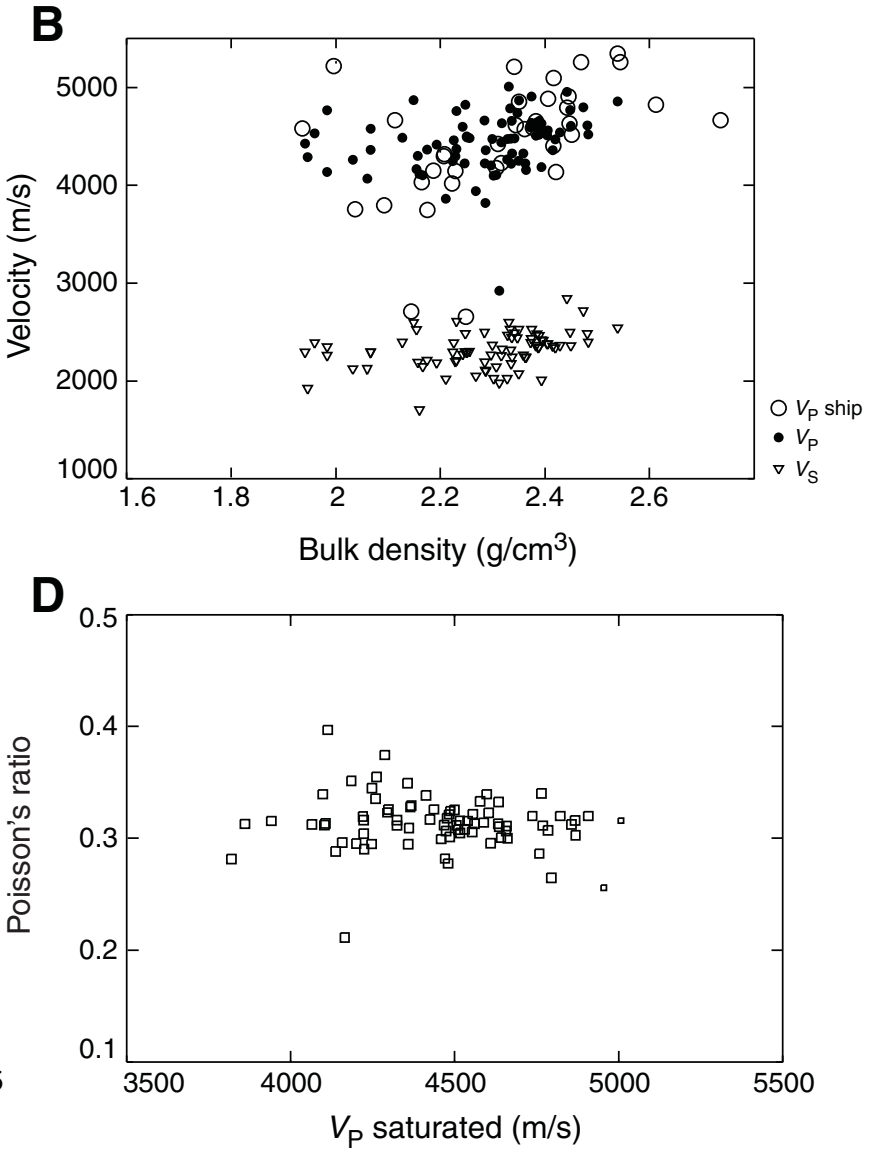
Figure F5. Core summaries. MS = magnetic susceptibility. Triangles = laboratory acoustic velocity discrete measurements, rectangles = shipboard discrete measurements. A. Hole M0017A. B. Hole M0023B. (Continued on next page.)
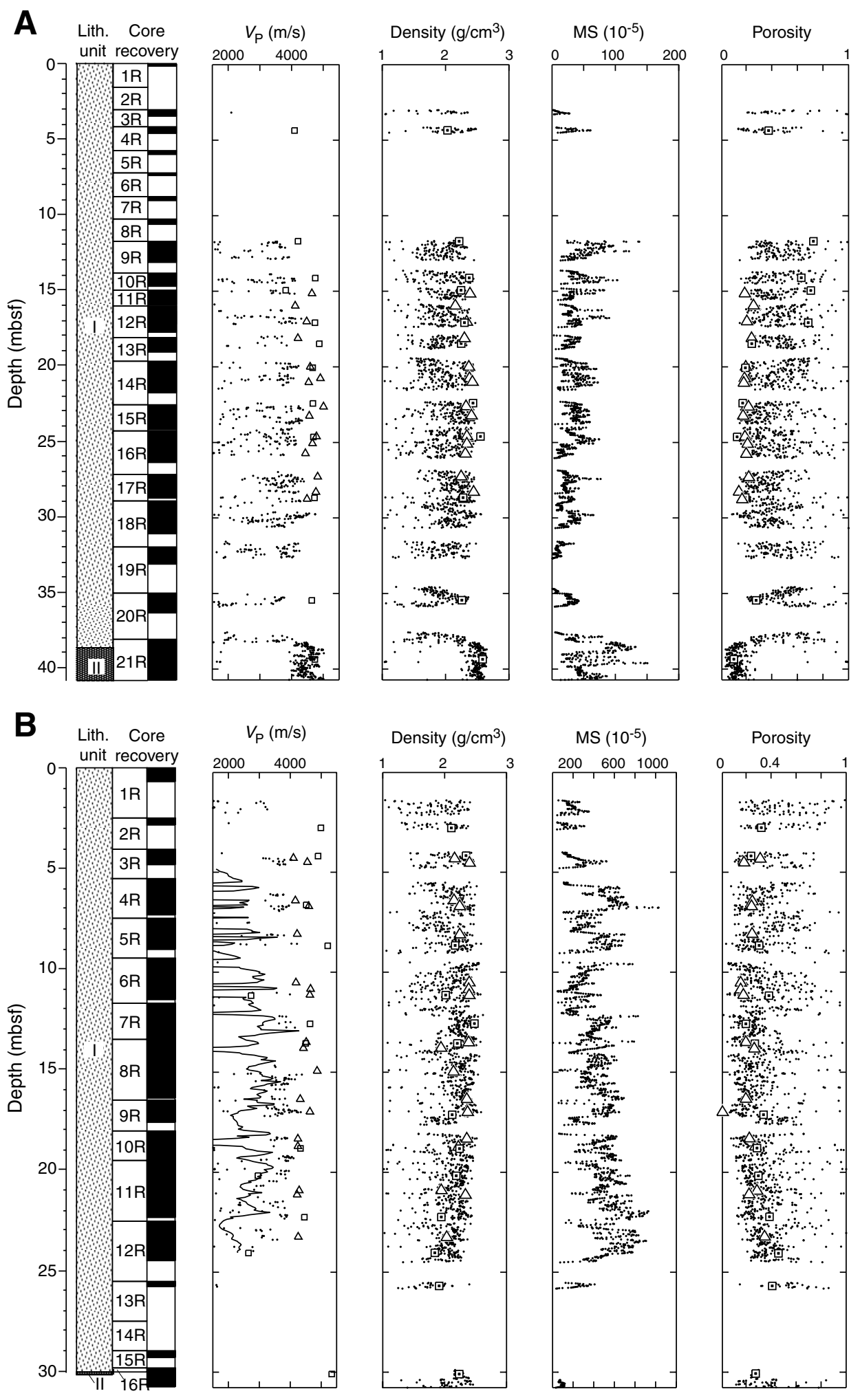
Figure F5 (continued). C. Hole M0005D.

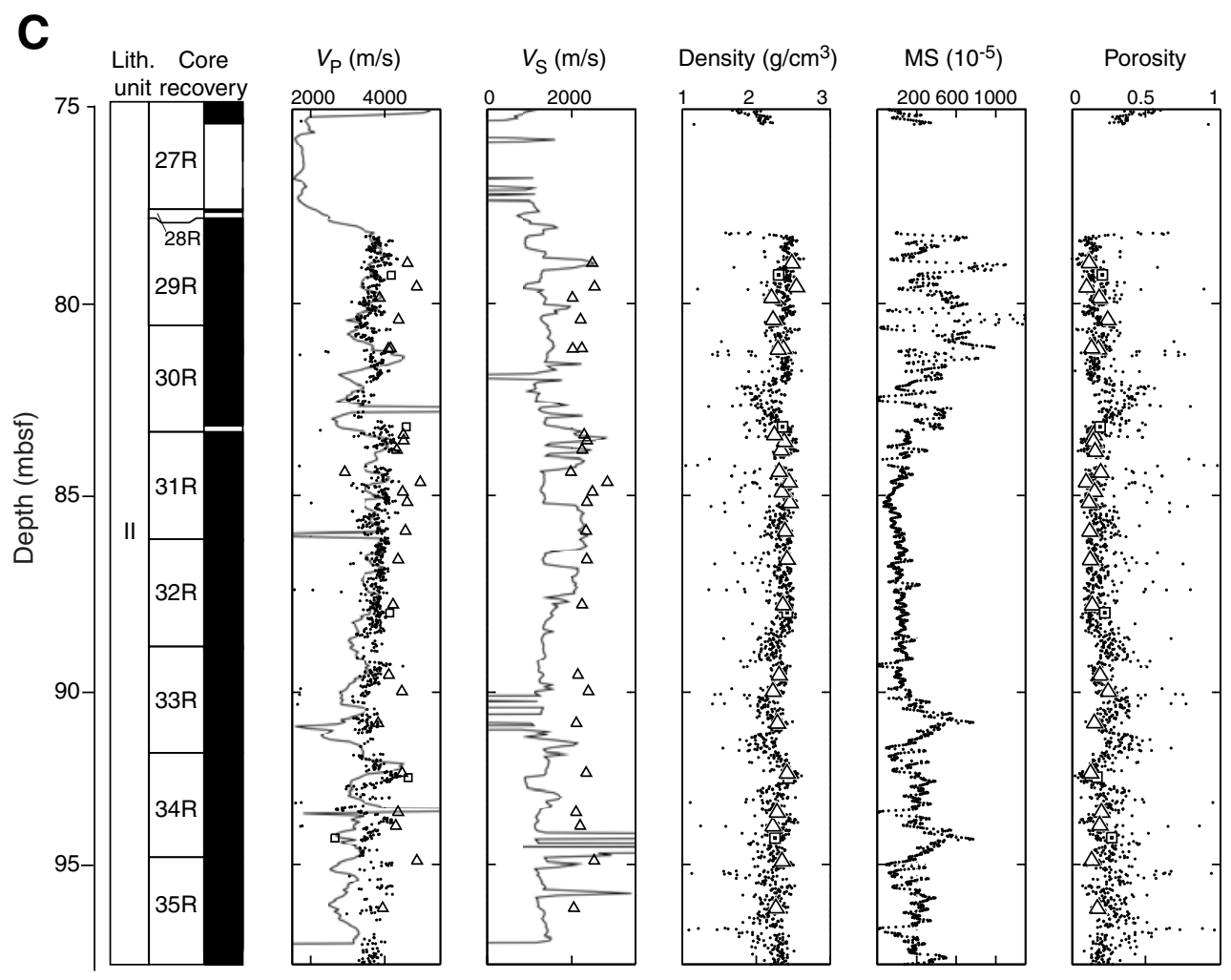


Figure F6. Cross-plots of porosity vs. $P$-wave velocity derived from core-log data. Triangles = discrete laboratory measurements, rectangles $=$ discrete shipboard measurements. Solid lines $=$ time-average equation for solidphase velocities of $6.5 \mathrm{~km} / \mathrm{s}$ (calcite), dashed lines = Raymer equation for solid-phase velocities of $6.5 \mathrm{~km} / \mathrm{s}$ (calcite).
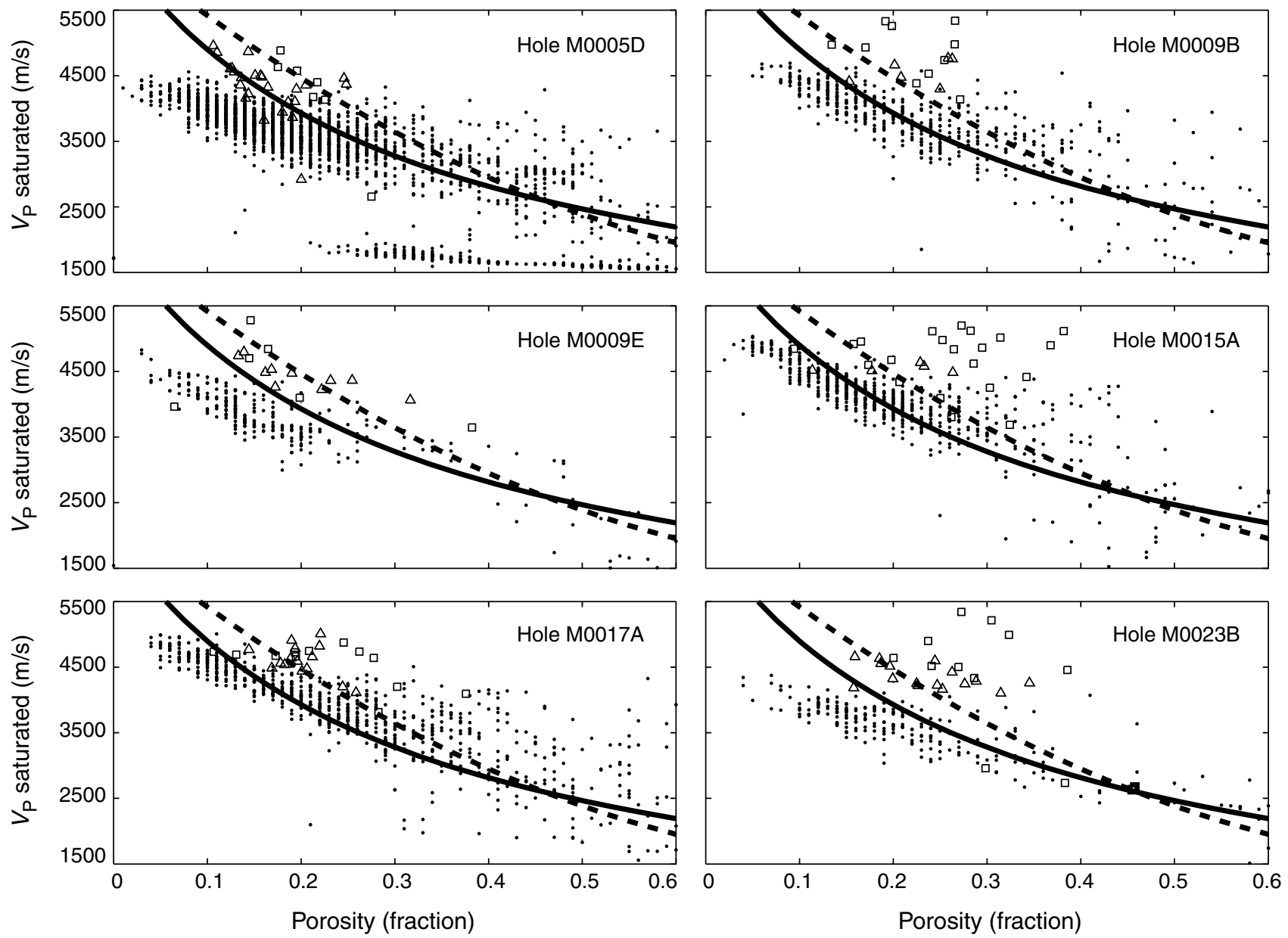
Figure F7. A. Cross-plot of velocity vs. porosity colored for carbonate content. Solid line = Wyllie (time-average) equation, dashed line $=$ Raymer equation. B. Diagram of relationship between acoustic velocity and fraction of noncarbonate content.

A

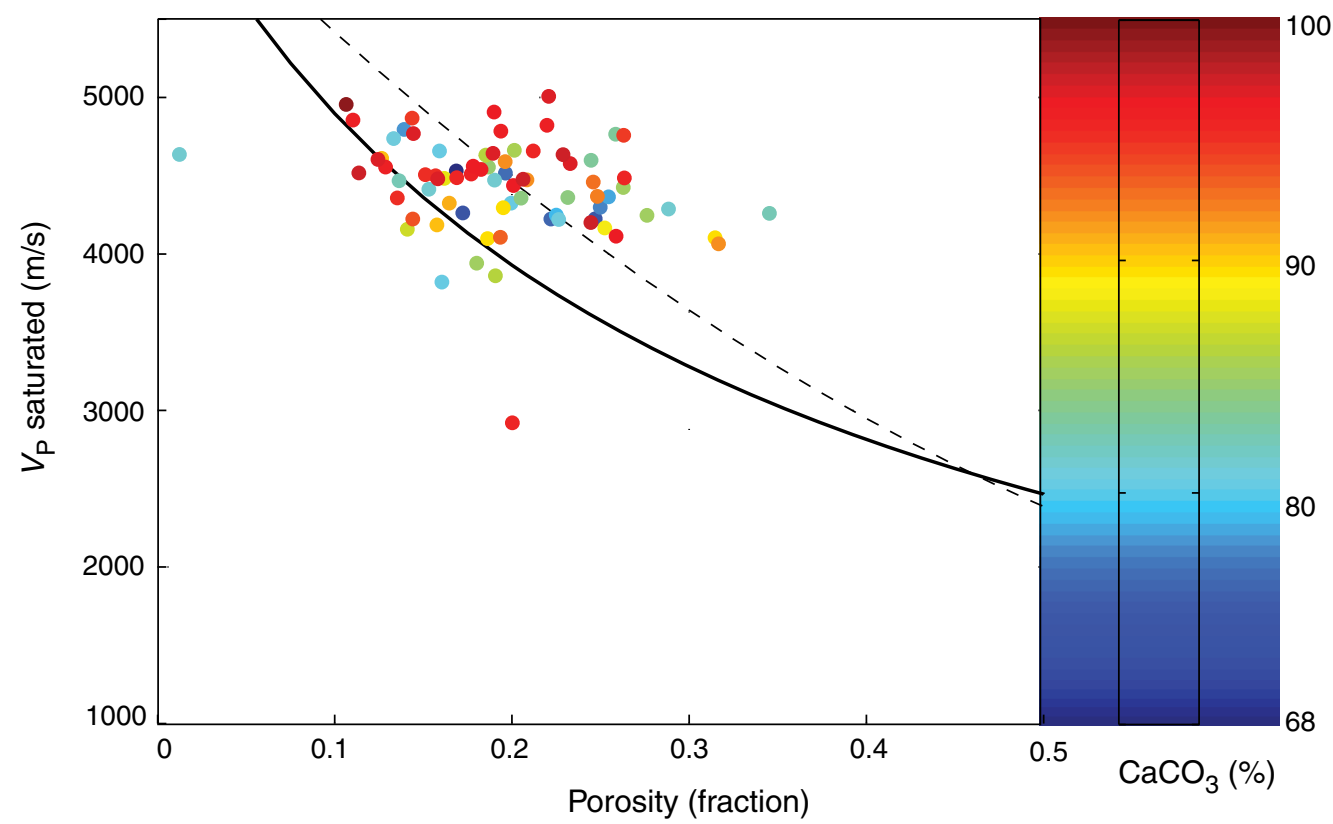

B

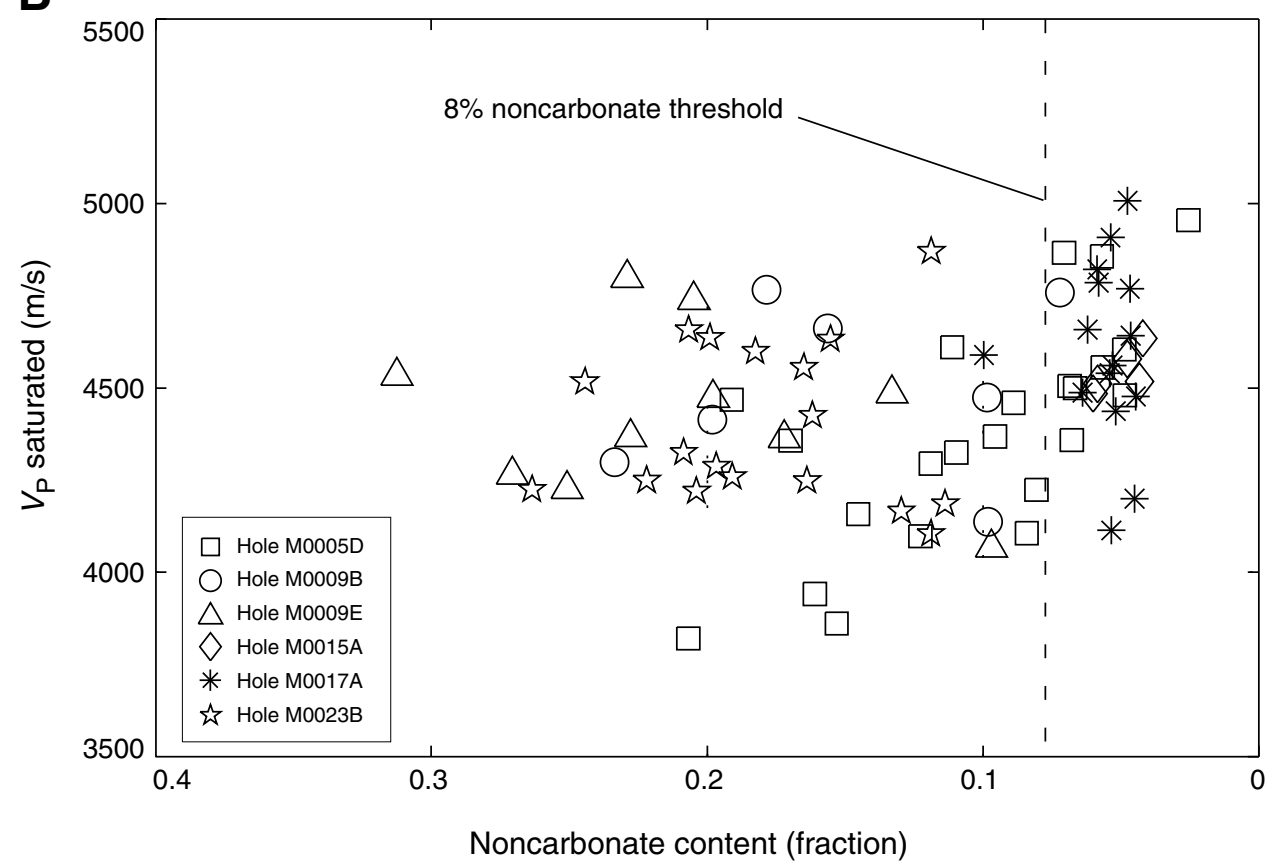


Figure F8. Cross-plot of Poisson's ratio vs. $P$-wave velocity for the Tahiti data set along with various literature data sets (Limburg Quarry, Kenter et al. 1997a; Florida Keys, Anselmetti et al., 1997; Last Chance Canyon, Kenter et al. 1997b). Data sets have been discriminated for noncarbonate content ( $8 \%$ threshold) and the presence of clay ( $>8 \%$ threshold). Immature clean carbonate data sets (Limburg Quarry and Florida Keys) are situated in the upper left quadrant. Tahiti sample set is separated at $4500 \mathrm{~m} / \mathrm{s}$ by the presence of $>8 \%$ noncarbonate material. Last Chance Canyon data also show portioning after mineralogy but have experienced burial diagenesis with significant lower Poisson's ratios as result.

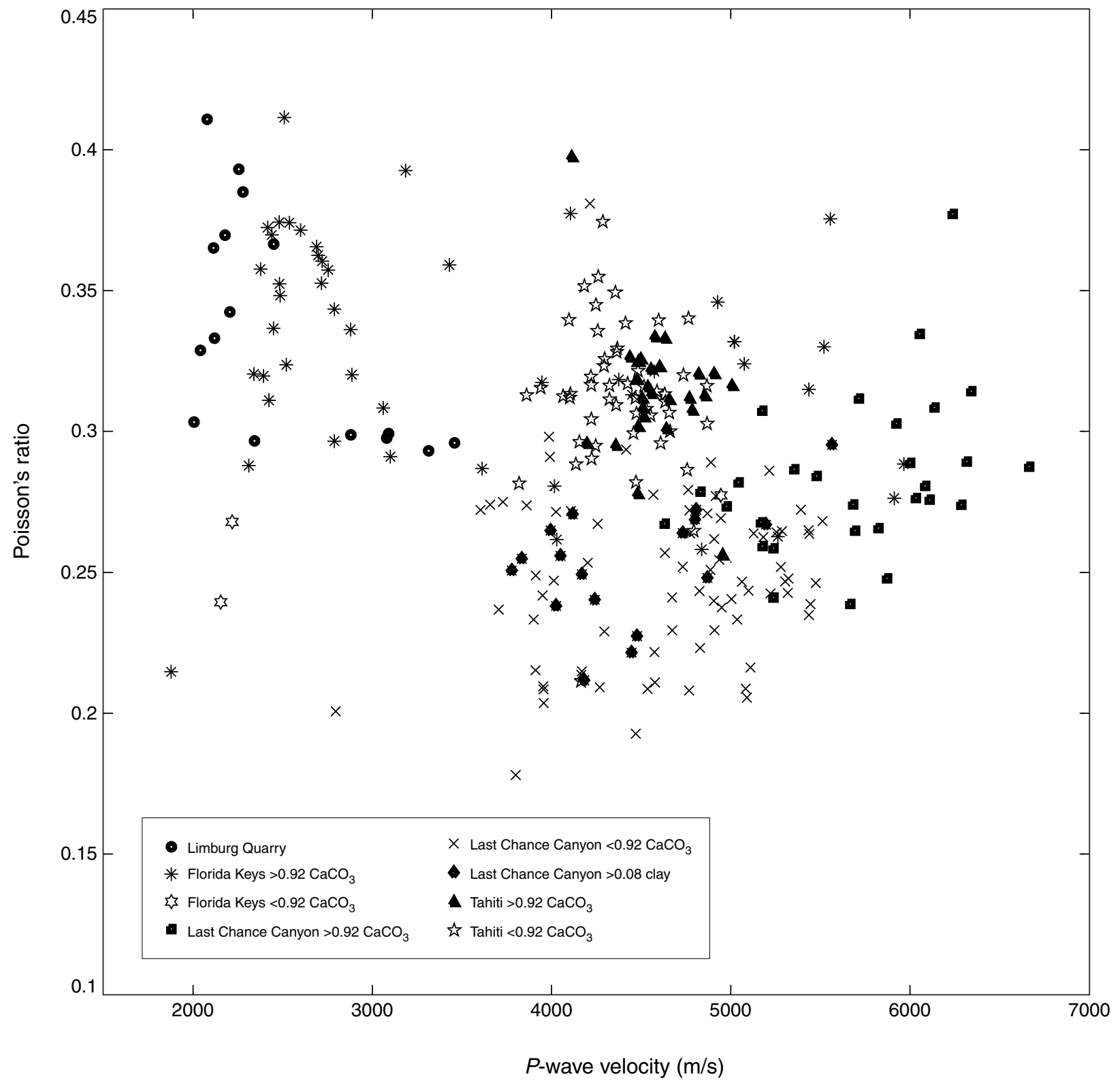


Figure F9. Cross-plots of acoustic velocity vs. porosity and density undifferentiated for mineralogy. A. Velocity vs. porosity with time-average transforms of Wyllie et al. (1956) for various matrix velocities (solid lines). B. Velocity vs. density with Gardner's equation (1974) for limestones (solid line) and Anselmetti-Eberli equation (1993) (dashed line). C. Velocity vs. porosity with best-fit linear regression lines plotted for all three sample groups. Large dashed line = Unit I, Maraa; medium dashed line = Unit I, Tiarei; small dashed line = Unit II.
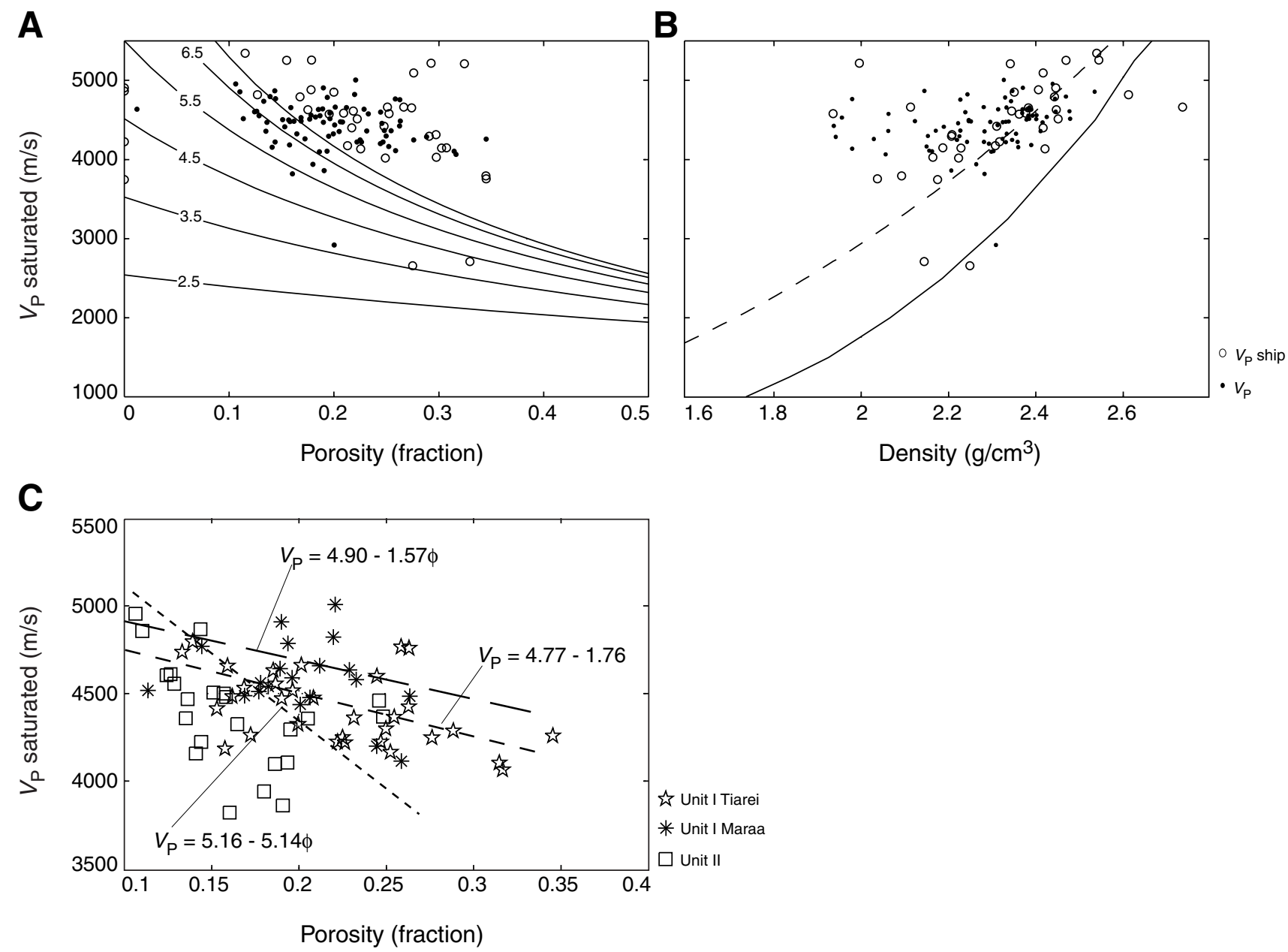
Table T1. Summary of index properties and acoustic properties, Site Maraa. (See table notes.)

\begin{tabular}{|c|c|c|c|c|c|c|c|c|}
\hline \multirow{2}{*}{$\begin{array}{l}\text { Core, section, } \\
\text { interval }(\mathrm{cm})\end{array}$} & \multirow{2}{*}{$\begin{array}{l}\text { Depth } \\
\text { (mbsf) }\end{array}$} & \multicolumn{2}{|c|}{ Density $\left(\mathrm{g} / \mathrm{cm}^{3}\right)$} & \multirow{2}{*}{$\begin{array}{c}\text { Porosity } \\
\text { (fraction) }\end{array}$} & \multicolumn{2}{|c|}{ Velocity $(\mathrm{m} / \mathrm{s})$} & \multirow[b]{2}{*}{$V_{\mathrm{p}} / V_{\mathrm{S}}$} & \multirow{2}{*}{$\begin{array}{l}\mathrm{CaCO} \\
(\mathrm{wt} \%)\end{array}$} \\
\hline & & Bulk & Grain & & $V_{\mathrm{P}}$ & $V_{s}$ & & \\
\hline \multicolumn{9}{|l|}{ 310-M0005D- } \\
\hline 29R-1, 81 & 78.95 & 2.48 & 2.9072 & 0.13 & 4610 & 2483 & 1.86 & 88.88 \\
\hline $29 \mathrm{R}-1,142$ & 79.56 & 2.54 & 2.8645 & 0.11 & 4856 & 2538 & 1.91 & 94.31 \\
\hline $29 \mathrm{R}-2,21$ & 79.85 & 2.21 & 3.6896 & 0.19 & 3861 & 2016 & 1.92 & 84.70 \\
\hline $29 \mathrm{R}-2,77$ & 80.41 & 2.23 & 3.0001 & 0.25 & 4368 & 2204 & 1.98 & 90.44 \\
\hline $30 \mathrm{R}-1,1$ & 81.15 & 2.36 & 2.8920 & 0.14 & 4157 & 2237 & 1.86 & 85.47 \\
\hline $30 \mathrm{R}-1,2$ & 81.16 & 2.30 & 3.0272 & 0.19 & 4098 & 2021 & 2.03 & 87.74 \\
\hline $30 \mathrm{R}-2,71$ & 83.37 & 2.25 & 2.7987 & 0.16 & 4499 & 2290 & 1.97 & 93.34 \\
\hline $30 \mathrm{R}-2,86$ & 83.52 & 2.38 & 3.0474 & 0.15 & 4506 & 2358 & 1.91 & 93.14 \\
\hline $30 \mathrm{R}-2,110$ & 83.76 & 2.34 & 2.9982 & 0.16 & 4324 & 2242 & 1.93 & 89.03 \\
\hline $31 \mathrm{R}-1,19$ & 84.33 & 2.31 & 2.8671 & 0.20 & 2920 & 1977 & 1.48 & 93.67 \\
\hline $31 \mathrm{R}-1,45$ & 84.59 & 2.44 & 2.8622 & 0.11 & 4955 & 2839 & 1.75 & 97.46 \\
\hline $31 \mathrm{R}-1,70$ & 84.84 & 2.34 & 2.8230 & 0.16 & 4480 & 2487 & 1.80 & 95.15 \\
\hline $31 \mathrm{R}-1,94$ & 85.10 & 2.45 & 2.9202 & 0.12 & 4604 & 2357 & 1.95 & 95.13 \\
\hline $31 \mathrm{R}-2,58$ & 85.84 & 2.39 & 2.8463 & 0.13 & 4555 & 2336 & 1.95 & 94.35 \\
\hline $31 \mathrm{R}-3,51$ & 86.58 & 2.41 & 2.9738 & 0.14 & 4358 & 2352 & 1.85 & 93.23 \\
\hline $32 \mathrm{R}-1,60$ & 87.74 & 2.36 & 2.8172 & 0.14 & 4223 & 2240 & 1.89 & 91.94 \\
\hline $32 \mathrm{R}-2,91$ & 89.55 & 2.31 & 3.0970 & 0.19 & 4106 & 2142 & 1.92 & 91.59 \\
\hline $32 \mathrm{R}-3,2$ & 89.97 & 2.23 & 2.8791 & 0.25 & 4459 & 2387 & 1.87 & 91.10 \\
\hline $33 \mathrm{R}-1,65$ & 90.79 & 2.29 & 2.9340 & 0.16 & 3820 & 2107 & 1.81 & 79.31 \\
\hline $33 \mathrm{R}-2,61$ & 92.07 & 2.42 & 2.8867 & 0.14 & 4468 & 2337 & 1.91 & 80.89 \\
\hline $33 \mathrm{R}-3,22$ & 93.08 & 2.29 & 2.6937 & 0.21 & 4357 & 2098 & 2.08 & 83.03 \\
\hline $34 \mathrm{R}-1,29$ & 93.43 & 2.23 & 2.9273 & 0.20 & 4295 & 2196 & 1.96 & 88.10 \\
\hline $34 \mathrm{R}-1,119$ & 94.33 & 2.35 & 2.9093 & 0.14 & 4867 & 2524 & 1.93 & 92.94 \\
\hline $34 \mathrm{R}-2,92$ & 95.55 & 2.27 & 3.0069 & 0.18 & 3941 & 2047 & 1.93 & 83.91 \\
\hline \multicolumn{9}{|l|}{ 310-M0015A- } \\
\hline 21R-1, 38 & 21.28 & 2.32 & 2.9154 & 0.23 & 4634 & 2321 & 2.00 & 95.80 \\
\hline $23 \mathrm{R}-1,28$ & 22.31 & 2.07 & 2.8349 & 0.23 & 4578 & 2291 & 2.00 & 95.25 \\
\hline $23 \mathrm{R}-1,38$ & 22.41 & 2.13 & 2.9382 & 0.26 & 4485 & 2392 & 1.88 & 93.99 \\
\hline $24 \mathrm{R}-1,7$ & 23.30 & 2.48 & 2.882 & 0.11 & 4517 & 2394 & 1.89 & 95.69 \\
\hline $26 \mathrm{R}-1,4$ & 24.89 & 2.40 & 2.9275 & 0.18 & 4511 & 2378 & 1.90 & 94.17 \\
\hline \multicolumn{9}{|l|}{ 310-M0017A- } \\
\hline 11R-1, 33 & 15.13 & 2.38 & 2.8341 & 0.19 & 4642 & 2480 & 1.87 & 95.37 \\
\hline $12 \mathrm{R}-1,9$ & 15.95 & 2.16 & 2.8536 & 0.26 & 4113 & 1700 & 2.42 & 94.67 \\
\hline $12 \mathrm{R}-1,113$ & 16.99 & 2.34 & 2.7975 & 0.21 & 4477 & 2313 & 1.94 & 95.55 \\
\hline 13R-1, 19 & 18.09 & 2.30 & 2.8775 & 0.24 & 4200 & 2264 & 1.86 & 95.50 \\
\hline $14 \mathrm{R}-1,57$ & 19.99 & 2.37 & 2.7742 & 0.20 & 4589 & 2390 & 1.92 & 90.03 \\
\hline $14 \mathrm{R}-1,132$ & 20.74 & 2.37 & 2.7182 & 0.19 & 4907 & 2525 & 1.94 & 94.63 \\
\hline $14 \mathrm{R}-2,7$ & 21.01 & 2.43 & 2.9704 & 0.18 & 4539 & 2357 & 1.93 & 94.59 \\
\hline $15 \mathrm{R}-1,32$ & 22.62 & 2.33 & 2.8239 & 0.22 & 5007 & 2598 & 1.93 & 95.25 \\
\hline $15 \mathrm{R}-1,93$ & 23.23 & 2.41 & 2.8136 & 0.18 & 4560 & 2379 & 1.92 & 94.70 \\
\hline $16 \mathrm{R}-1,60$ & 24.59 & 2.33 & 2.7002 & 0.19 & 4785 & 2525 & 1.90 & 94.20 \\
\hline $16 \mathrm{R}-1,106$ & 25.05 & 2.34 & 2.8481 & 0.21 & 4658 & 2441 & 1.91 & 93.80 \\
\hline 16R-2, 22 & 25.71 & 2.32 & 2.8705 & 0.20 & 4437 & 2255 & 1.97 & 94.81 \\
\hline $17 \mathrm{R}-1,40$ & 27.25 & 2.25 & 2.875 & 0.22 & 4822 & 2482 & 1.94 & 94.14 \\
\hline $17 \mathrm{R}-1,142$ & 28.27 & 2.45 & 2.9108 & 0.14 & 4769 & 2497 & 1.91 & 95.33 \\
\hline 18R-1, 17 & 28.73 & 2.25 & 2.7498 & 0.17 & 4487 & 2288 & 1.96 & 93.61 \\
\hline
\end{tabular}

Notes: $V_{\mathrm{P}}=P$-wave velocity, $V_{\mathrm{S}}=S$-wave velocity. $\mathrm{CaCO}_{3}=$ carbonate fraction determined with thermogravimetric analysis. 
Table T2. Summary of index properties and acoustic properties, Site Tiarei. (See table notes.)

\begin{tabular}{|c|c|c|c|c|c|c|c|c|}
\hline \multirow{2}{*}{$\begin{array}{l}\text { Core, section, } \\
\text { interval }(\mathrm{cm})\end{array}$} & \multirow{2}{*}{$\begin{array}{l}\text { Depth } \\
\text { (mbsf) }\end{array}$} & \multicolumn{2}{|c|}{ Density $\left(\mathrm{g} / \mathrm{cm}^{3}\right)$} & \multirow{2}{*}{$\begin{array}{l}\text { Porosity } \\
\text { (fraction) }\end{array}$} & \multicolumn{2}{|c|}{ Velocity $(\mathrm{m} / \mathrm{s})$} & \multirow[b]{2}{*}{$V_{\mathrm{P}} / V_{\mathrm{S}}$} & \multirow{2}{*}{$\begin{array}{l}\mathrm{CaCO}_{3} \\
\text { (wt\%) }\end{array}$} \\
\hline & & Bulk & Grain & & $V_{\mathrm{P}}$ & $V_{S}$ & & \\
\hline \multicolumn{9}{|l|}{ 310-M0009B- } \\
\hline $5 R-1,47$ & 5.60 & 2.19 & 2.7484 & 0.15 & 4413 & 2182 & 2.02 & 80.19 \\
\hline $6 \mathrm{R}-1,33$ & 6.22 & 2.16 & 3.0464 & 0.25 & 4298 & 2186 & 1.97 & 76.65 \\
\hline $7 R-1,53$ & 7.42 & 2.30 & 2.9391 & 0.21 & 4474 & 2364 & 1.89 & 90.15 \\
\hline $8 R-1,58$ & 8.37 & 2.28 & 2.8897 & 0.20 & 4662 & 2492 & 1.87 & 84.37 \\
\hline $9 \mathrm{R}-1,10$ & 8.92 & 1.98 & 2.9027 & 0.26 & 4765 & 2346 & 2.03 & 82.16 \\
\hline $10 \mathrm{R}-1,28$ & 11.10 & 1.98 & 2.8765 & - & 4137 & 2257 & 1.83 & 90.19 \\
\hline $11 \mathrm{R}-1,88$ & 13.48 & 2.23 & 2.8843 & 0.26 & 4758 & 2604 & 1.83 & 92.79 \\
\hline \multicolumn{9}{|l|}{ 310-M0009E- } \\
\hline $2 \mathrm{R}-2,42$ & 3.46 & 2.29 & 2.9379 & 0.22 & 4223 & 2189 & 1.93 & 74.92 \\
\hline $2 \mathrm{R}-2,78$ & 3.72 & 2.06 & 2.9563 & 0.32 & 4065 & 2124 & 1.91 & 90.30 \\
\hline $3 R-1,66$ & 5.00 & 2.17 & 2.8202 & 0.25 & 4365 & 2208 & 1.98 & 77.22 \\
\hline $4 \mathrm{R}-1,72$ & 7.80 & 1.96 & 2.7668 & 0.17 & 4530 & 2387 & 1.90 & 68.75 \\
\hline $5 R-1,74$ & 9.03 & 2.33 & 2.8842 & 0.19 & 4471 & 2464 & 1.81 & 80.21 \\
\hline $6 \mathrm{R}-1,98$ & 10.64 & 2.26 & 2.8290 & 0.16 & 4483 & 2300 & 1.95 & 86.69 \\
\hline $7 R-1,14$ & 11.34 & 2.07 & 2.7969 & 0.23 & 4361 & 2292 & 1.90 & 82.79 \\
\hline $12 \mathrm{R}-2,47$ & 18.23 & 2.35 & 2.5792 & 0.13 & 4737 & 2438 & 1.94 & 79.52 \\
\hline $12 \mathrm{R}-3,19$ & 19.26 & 2.47 & 2.9373 & 0.14 & 4795 & 2713 & 1.77 & 77.10 \\
\hline $12 \mathrm{R}-4,94$ & 20.32 & 2.33 & 2.9521 & 0.17 & 4262 & 2022 & 2.11 & 72.94 \\
\hline \multicolumn{9}{|l|}{ 310-M0023B- } \\
\hline $3 R-1,28$ & 4.28 & 2.17 & 2.956 & 0.31 & 4103 & 2146 & 1.91 & 88.11 \\
\hline $3 R-1,49$ & 4.49 & 2.40 & 2.9094 & 0.19 & 4554 & 2410 & 1.89 & 83.51 \\
\hline 4R-1, 91 & 6.41 & 2.15 & 3.0067 & 0.25 & 4165 & 2520 & 1.65 & 87.05 \\
\hline $4 \mathrm{R}-1,119$ & 6.69 & 2.24 & 2.8684 & 0.24 & 4598 & 2268 & 2.03 & 81.75 \\
\hline $5 R-1,61$ & 8.08 & 2.25 & 2.9882 & 0.25 & 4224 & 2297 & 1.84 & 73.66 \\
\hline $6 \mathrm{R}-1,101$ & 10.51 & 2.39 & 2.9046 & 0.16 & 4185 & 2003 & 2.09 & 88.63 \\
\hline $6 \mathrm{R}-1,133$ & 10.83 & 2.39 & 2.9444 & 0.16 & 4657 & 2460 & 1.89 & 79.34 \\
\hline $6 \mathrm{R}-2,15$ & 11.12 & 2.39 & 2.9055 & 0.19 & 4632 & 2416 & 1.92 & 84.48 \\
\hline $7 R-2,140$ & 13.48 & 2.39 & 2.8562 & 0.20 & 4516 & 2343 & 1.93 & 75.58 \\
\hline $8 R-1,26$ & 13.79 & 1.94 & 2.8938 & 0.26 & 4425 & 2292 & 1.93 & 83.82 \\
\hline $8 \mathrm{R}-2,3$ & 14.93 & 2.15 & 2.9672 & - & 4869 & 2591 & 1.88 & 88.14 \\
\hline $8 \mathrm{R}-2,144$ & 16.34 & 2.36 & 2.8725 & 0.20 & 4324 & 2264 & 1.91 & 79.14 \\
\hline $9 \mathrm{R}-1,44$ & 16.97 & 2.37 & 2.971 & 0.01 & 4636 & 2431 & 1.91 & 80.10 \\
\hline $10 \mathrm{R}-1,26$ & 18.32 & 2.35 & 2.7867 & 0.22 & 4248 & 2068 & 2.05 & 77.82 \\
\hline 10R-1, 63 & 18.69 & 2.22 & 2.8454 & 0.28 & 4247 & 2291 & 1.85 & 83.62 \\
\hline 11R-1, 138 & 20.90 & 1.95 & 2.8625 & 0.29 & 4287 & 1921 & 2.23 & 80.34 \\
\hline $11 \mathrm{R}-2,6$ & 21.11 & 2.34 & 2.9363 & 0.23 & 4220 & 2174 & 1.94 & 79.61 \\
\hline $12 \mathrm{R}-2,17$ & 23.22 & 2.03 & 2.9034 & 0.35 & 4259 & 2119 & 2.01 & 80.92 \\
\hline
\end{tabular}

Notes: $V_{\mathrm{P}}=P$-wave velocity, $V_{\mathrm{S}}=S$-wave velocity. $\mathrm{CaCO}_{3}=$ carbonate fraction determined with thermogravimetric analysis. $-=$ no data. 